\title{
Research Paper \\ A Comparative Study of the Effectiveness of Cognitive Rehabilitation Intervention with Aerobic Exercises on the Cognition of Slow Learner Children
}

\author{
Kobra Abazari Gharebelagh ${ }^{* 1}$, Nahid Mohammadi Darvish Baghal ${ }^{2}$ \\ 1. Ph.D. in Psychology of Children with Special Needs, Instructor at Farhangian University, Tehran, Iran \\ 2. Ph.D. in Educational Psychology, Educational Counselor, Islamshahr, Tehran, Iran
}

Citation: Abazari Gharebelagh K, Mohammadi Darvish Baghal N. A comparative study of the effectiveness of cognitive rehabilitation intervention with aerobic exercises on the cognition of slow learner children. Quarterly Journal of Child Mental Health. 2019; 6(3): 149-161.

http://dx.doi.org/10.29252/jcmh.6.3.14

\section{A R T I C L E I N F O}

\begin{tabular}{l}
\hline Keywords: \\
Aerobics, \\
visual, \\
cognition, \\
cognitive rehabilitation, \\
slow learning children
\end{tabular}

Received: 26 Nov 2017

Accepted: 03 Jul 2018

Available: 9 Nov 2019

\section{A B S T R A C T}

Background and Purpose: Slow learner children have some problems with cognitive components (memory and attention) and are not able to learn and solve problems like their peers. Familiarity with techniques and instruments affecting the brain and enhancing the cognition is now the main concern of the professionals. This research was conducted to compare the effectiveness of cognitive interventions and aerobic exercises on the cognition of slow learner children.

Method: This study was a semi-experimental research of pretest-posttest control group design. The participants included all the 36 slow learner primary school students of Islamshahr city (in Tehran province) in 2017 , which had been selected by convenience sampling. This sample was divided into 3 groups of cognitive rehabilitation, aerobic exercises, and control (12 per group). For 2 months, the interventions were administrated in 50-60 minute sessions, 3 times per week. Finally, all the three groups were administrated the posttest to investigate the effectiveness of the interventions. To measure the intelligence and cognitive characteristics of the students, Stanford-Binet Intelligence Scale (2003) was used. To analyze the data, multivariate analysis of covariance was used.

Results: Results showed that there was a significant difference between the 3 groups in the visual memory component $(P=0.027, F=2.737$, Wilks' Lambda $=0.273)$. Also, there was no significant difference between the rehabilitation and aerobic exercises groups in terms of cognitive variables (i.e., verbal and nonverbal working memories and visual verbal and nonverbal spatial processing), but the rehabilitation group had a significant difference $(P=0.014)$ with the control group in the nonverbal working memory scale (visual memory); i.e., both rehabilitation and aerobic groups performed well after intervention, but the cognitive rehabilitation group performed better than the aerobic group. Conclusion: Because cognitive rehabilitation focus on increasing working memory, according to the results of this research, a cognitive rehabilitation package can be used to increase the visual working memory in slow learner children at schools and rehabilitation centers in order to improve their educational status.

\footnotetext{
* Corresponding author: Kobra Abazari Gharebelagh, Ph.D. in Psychology of Children with Special Needs, Instructor at Farhangian University, Tehran, Iran.

E-mail addresses: Kabazari@yahoo.com
}

2476-5740/ (C) 2019 The Authors. This is an open access article under the CC BY-NC-ND license (https://creativecommons.org/licenses/by-nc-nd/3.0/). 


\section{مقايسه اثربخشى مداخله توانبخى شناختى با تمرينات ورزشى ايروبيك بر شناخت كود كان دير آموز

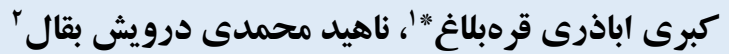

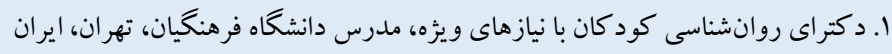

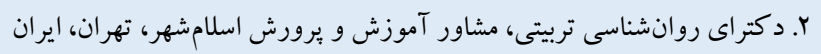

جكيu

زمينه و هدف: كود كان دير آموز، داراى مشكلاتى در مؤلفه هاى شـناختى (حافظه و توجه) هستند و قادر به فراكيرى مطالب و حل مسائل

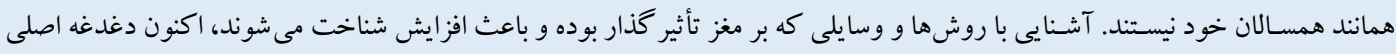

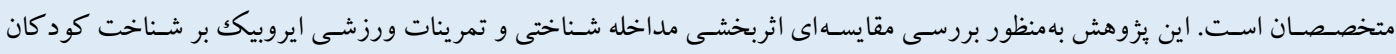

$$
\text { دير آموز انجام شد. }
$$

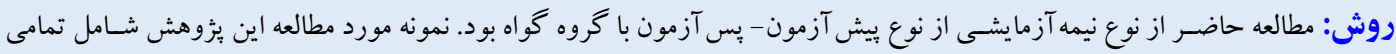

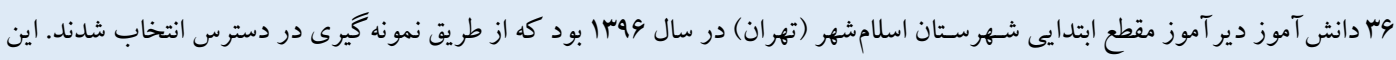

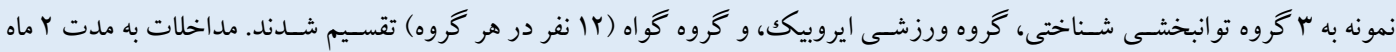

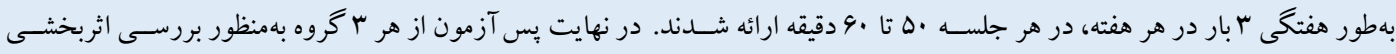

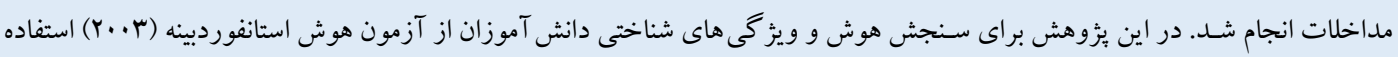

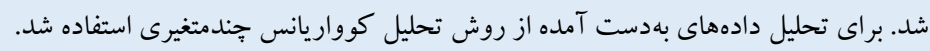

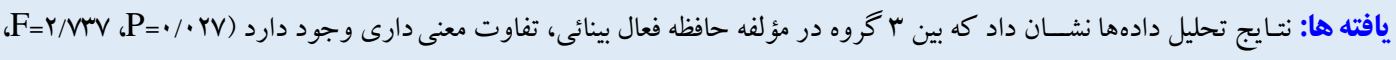

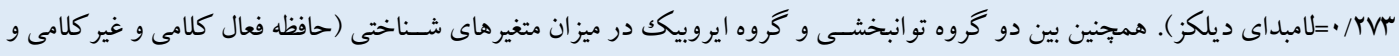

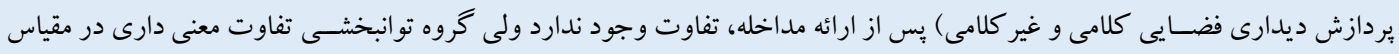

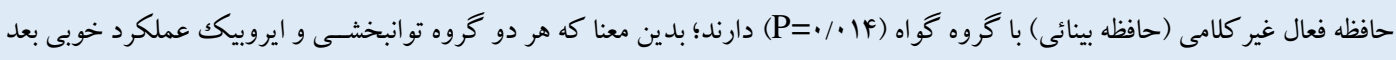

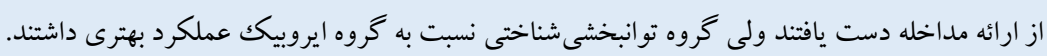

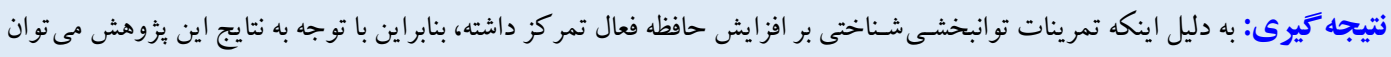

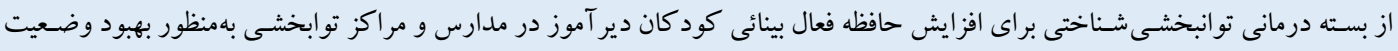

درسى اين دانش آموزان استفاده كرد.
مشخصات مقاله

كليدوازهها: ايروبيك، بينائى، شناخت، تو انبخشى شناختى، كود كان دير آموز

دريافت شده: ه/9/99/9 يذيرفته شده:

منتشر شده: \$N/

* نويسنده مسئول: كبرى اباذرى قرهبلاغ، دكتراى روانشناسى كود كان با نيازهاى خاص، مدرس دانشكاه فرهنكيان، تهران، ايران.

رايانه: Kabazari@yahoo.com

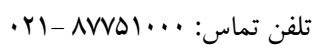


هوشى، تو انايى رياضسى، و كلامى مى شـود (V). يزوهش هاى فراتحليل

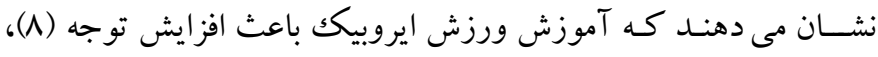

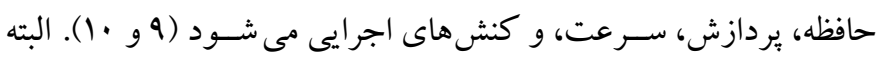

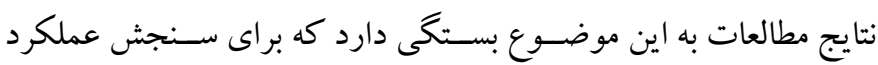

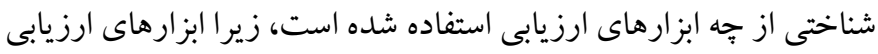
با حساسيت كمتر به تأثير فعاليت ورزشى و عملكرد شناختى دست نيافتند

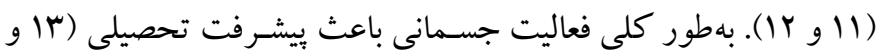

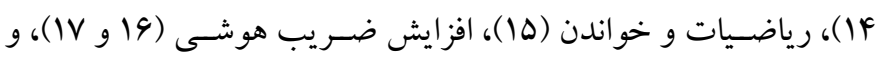
حافظه (1) ا و ا IV ) مىشود.

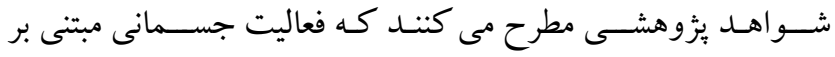

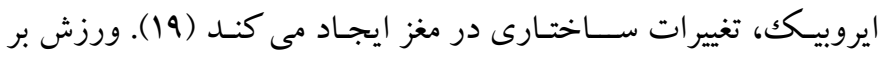
عملكرد شــناختى، تحصـيلى، و حر كتى دانش آموزان تأثير مثبتى دارد

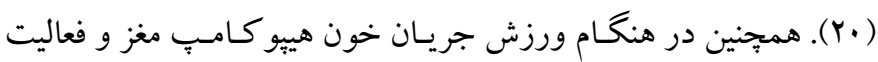
هييو كامب افزايش بيدا مى كند (Y) و حجم مغز بهطور قابل توجهى هم

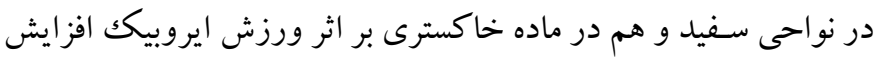

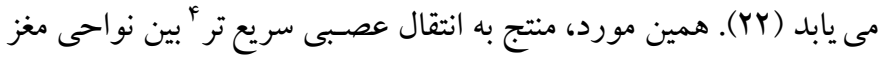

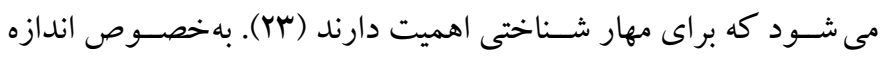

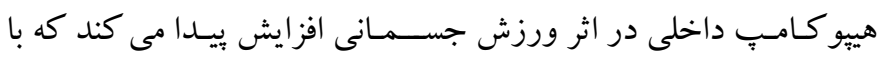

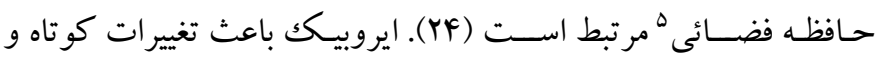
بلندمدت در نواحى مغزى مى شود كه براى ياد گيرى و حافظه بسيار مهم

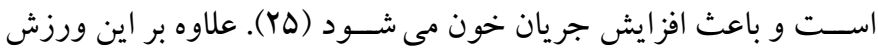

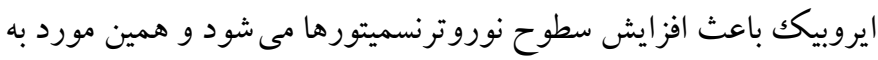

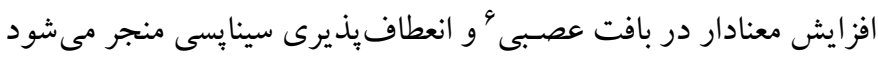

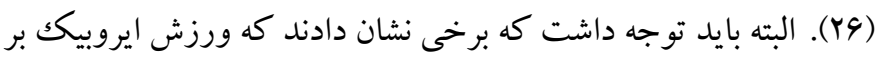

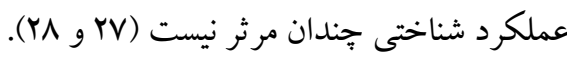
افراد با تاخيرات تحولى نسبت به افراد بدون تأخير تحولى، به تأثيرات

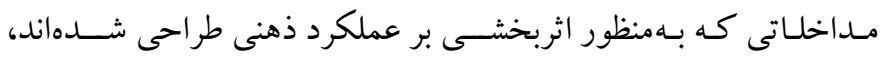

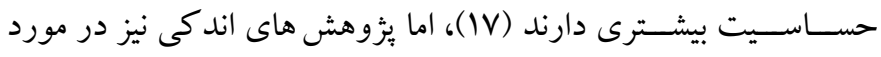
اثربخشـى حر كات جسـمانى بر عملكرد شــناختى و هوشـى كود كان

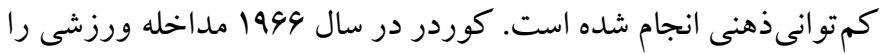

4. Neural conduction

5. Spatial memory

6. Neurogenesis
مقلدمه كود كان ديرآموز ' بهه علت تحول ذهنى كم، قادر به فراگيرى مطالب و

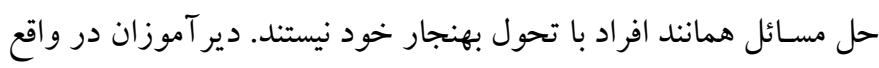

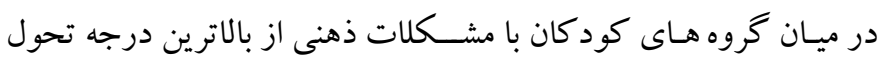

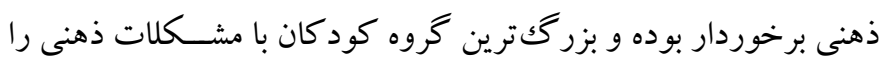

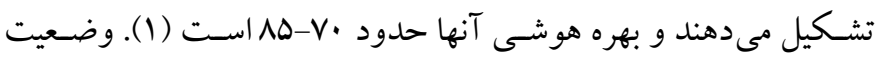

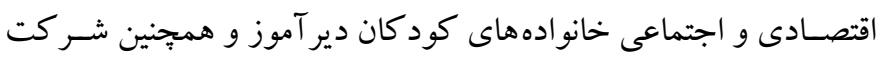

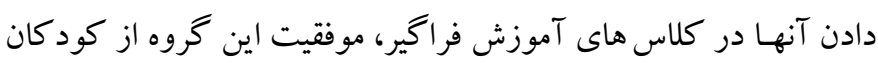

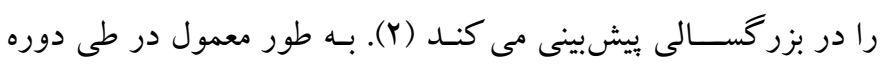

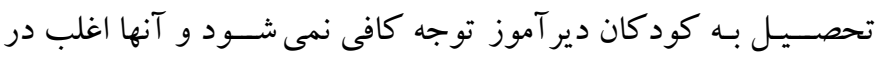

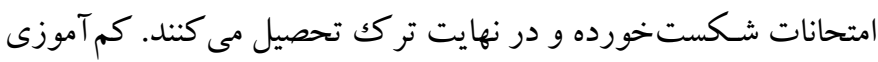

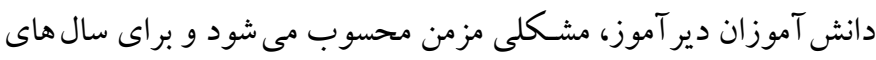

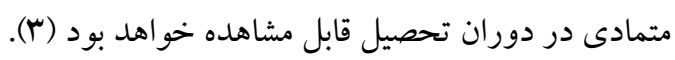

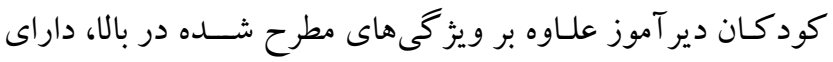

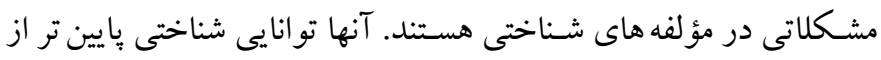

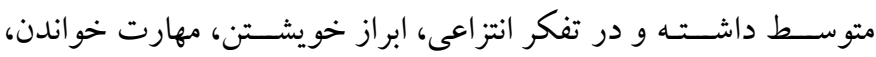

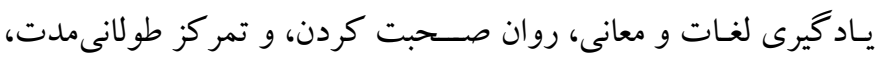

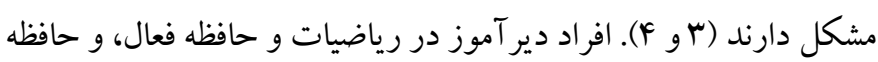

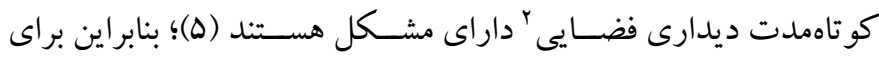

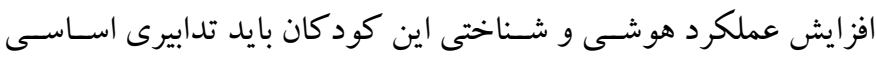
انديشيد.

آشنايى با موارد و وسايلى كه تأثير گذار بر مغز است و باعث افزايش شـاخت مى شود اكنون دلمشغولى بين متخصصصان و والدين است. در حال حاضر با اينكه تمركز زيادى بر استفاده از دارو در افزايش شناخت

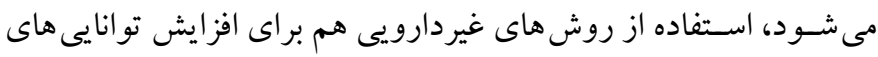

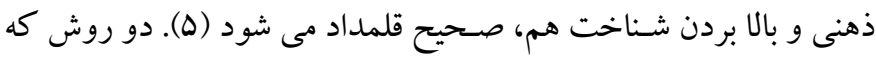

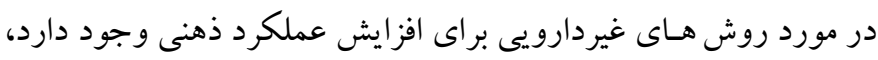
توانبخشى شناختى" و تمرين هاى جسمانى است

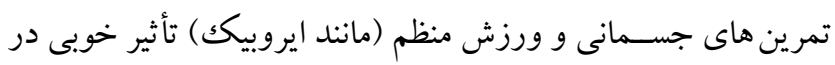
عملكرد مغز و شـــاخـت دارد (9). ورزش بـاعث افزايش مهارت هاى

1. Slow learners

2. Visual spatial short-term memory

3. Cognitive rehabilitation 
تو انايى ذهنى بهنجار و هم افراد با نارساكنشورى شناختى مورد استفاده

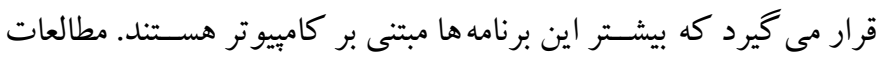

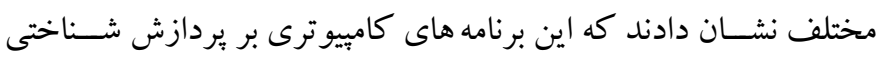

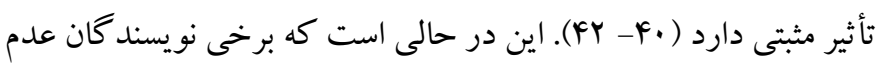

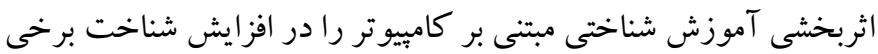

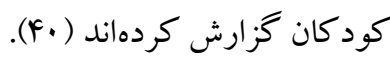

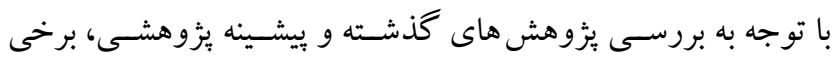

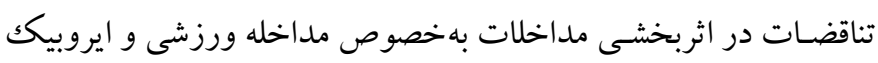

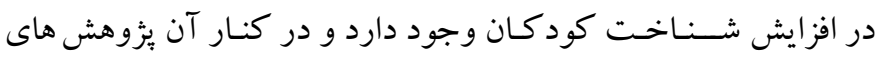

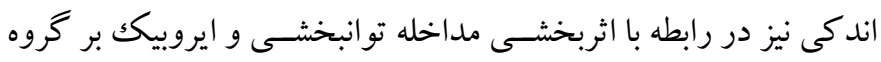
دانش آموزان بهخصـوص در سـال هاى ابتدايى مدرسـه انجام شـــه است.

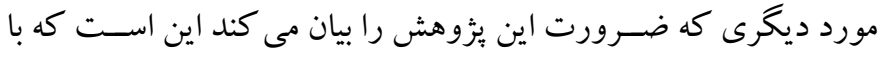
توجه به بررسى هاى انجام شده در اين مطالعه، يُووهشى كه به مقايسه دو

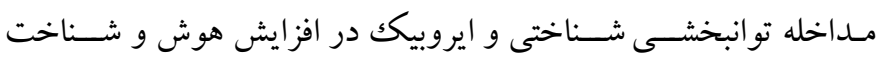

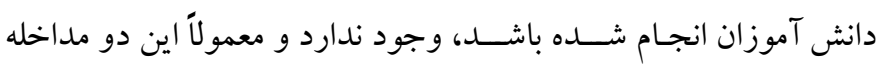
به تنهايى در مقايسه با گروه گُ اه به اين كود كان ارائه شده است.

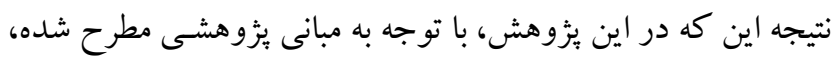

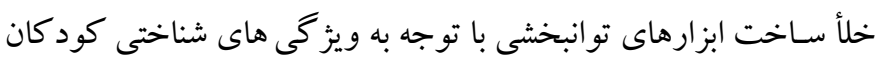

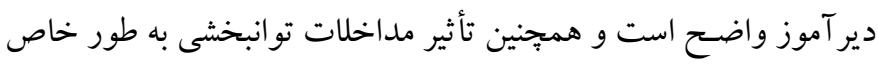

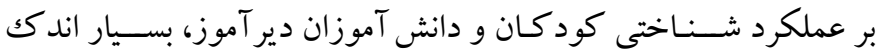

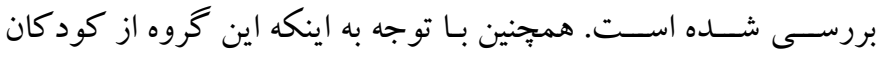

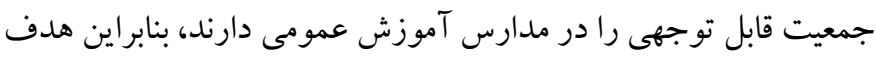

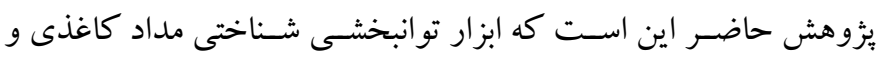

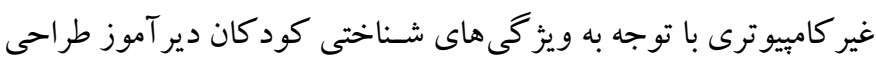

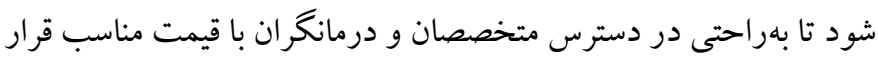

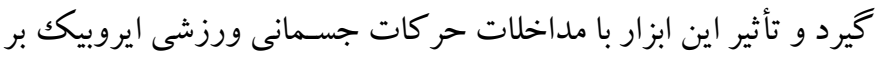
يشرفت شناخت كود كان دير آموز بررسى شود.

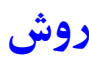
الف) طرح يزوهش و شـر كت كنند كان: طرح يزوهشى حاضر از نوع

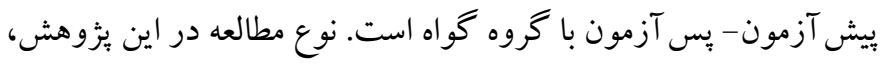

براى كود كان كم توانذهنى خفيف گروه سنى 19-Y ساله (YF كودكS)

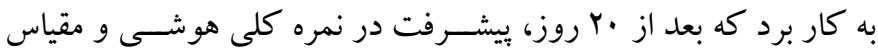

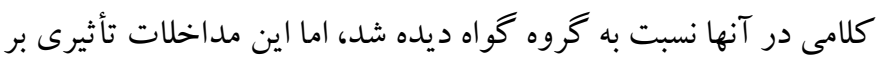

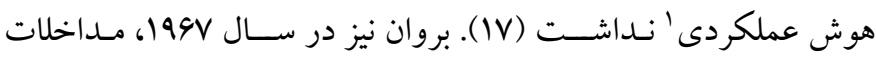

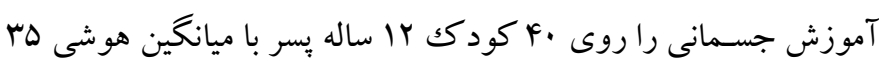

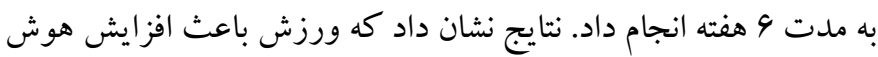

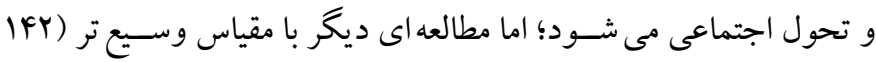

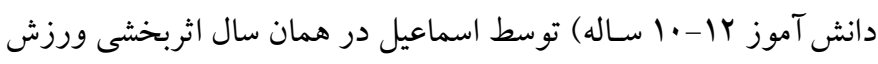

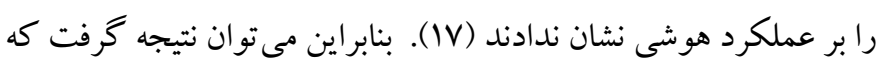
اثربخشى مثبت ورزش ايروبيكك بر عملكرد هوشى كود كان با مشكلات

ذهنى با قطعيت نشان داده نشده است (Yq).

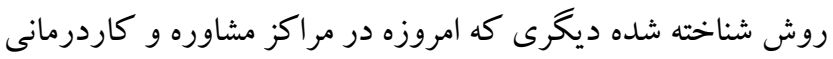

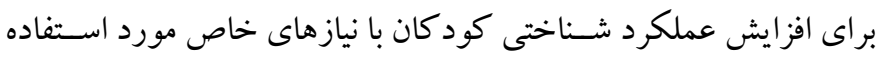

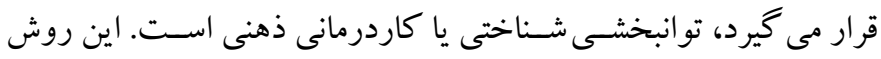

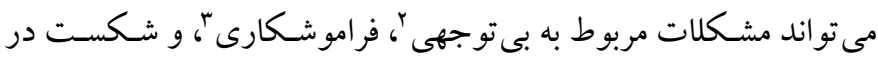

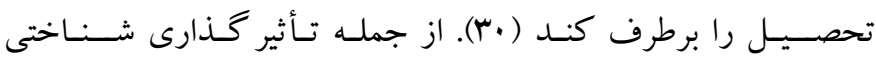
توانبخشى شناختى، اثربخشى بر حافظه فعال است (Iا).

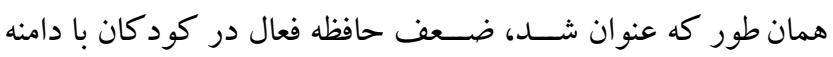
هوشى شه دسـت كارى اطلاعات در مغز در دوره زمانى كو تاه اطلاق مى شـود (بس). حافظه فعال در فعاليت هاى مدرسه اى مانند درك زبان، رياضيات (MF)،

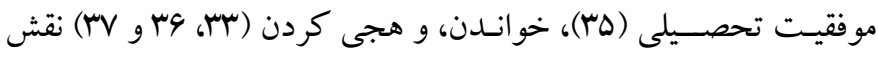

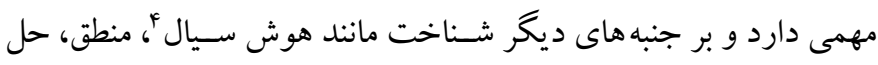

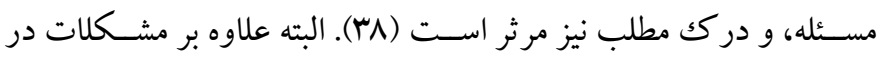

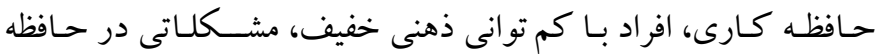

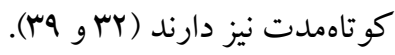
آموزش شـناختى به طور معمول هم در شـناخت و هم در رفتار تأثير

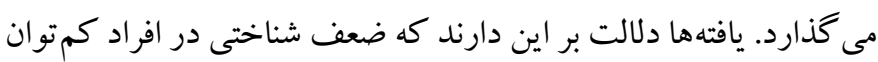
ذهنى با مداخلات مستمر در زمينه تو انبخشى شناختى بهبود مى يابد (Y) (Y).

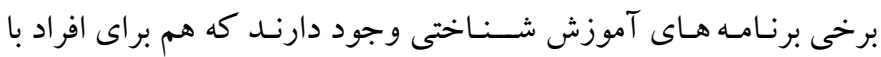

1. Performance IQ

2. Inattention 


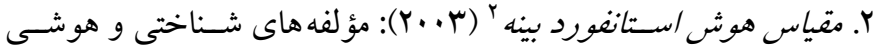
دانش آموزان (سـنجش هوش كلى، استـدلال سيال، حافظه فعال، استدلال كمى (رياضيات)، و يردازش ديدارى- فضايى) در اين يزوهش به به وسيله

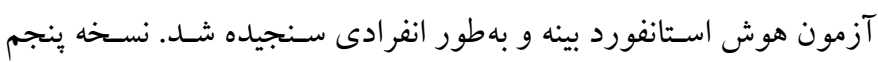

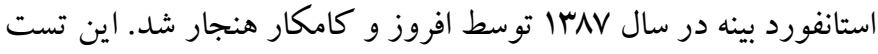

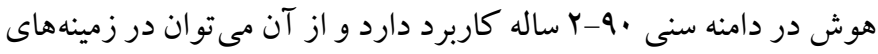

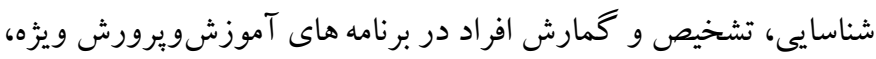

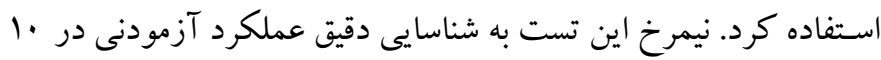

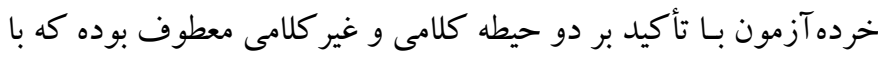
توجه به له عامل سـازنده هوش، · ا خردها آزمون را شامل مى شود. اين ده خردها آزمون در مقيـاس هـاى كلامى و غير كلامى عبارت اند از: اســـدلال

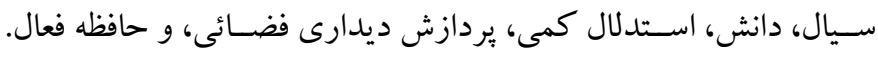

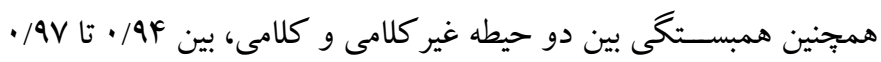

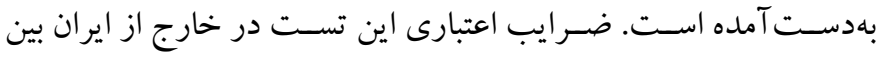

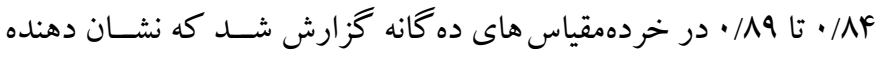
اعتبار بالاى اين ابزار در زمينه خردهآزمونها و نمرات تركيبى است (Fr).

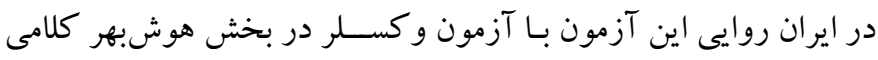

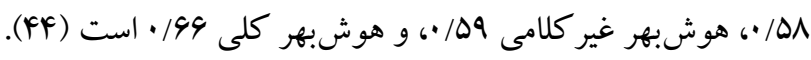
ج) برنامه مداخله اي: برنامه مداخله اي در اين مطالعه شــامل مداخلات توانبخشى و مداخله ايروبيكك براى دو گروه آزمايش شر كت كننده بوده.

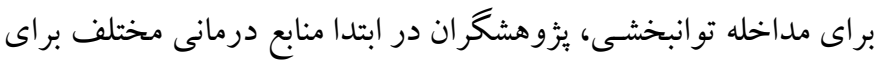

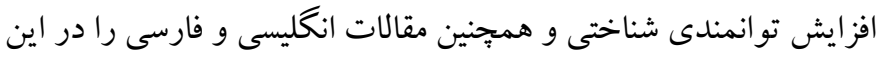

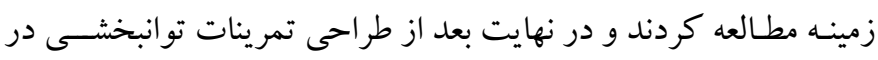

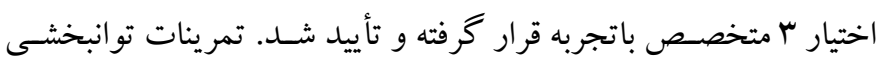
شناختى براى ^ هفته (YF جلسه و در هر هفته ب جلسه يكك روز در ميان) در هأ تا •ه دقيقه در هر جلسه به دانش آموزان ارائه شد. بهمنظور طر احى

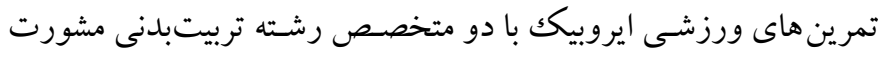

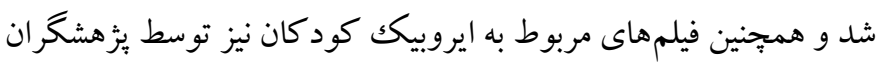

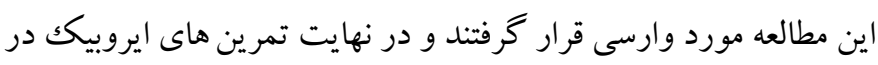
جF
نيمـهـ آزمـايشـى اسـت. جامعه آمارى در اين بُزوهش، تمامى كودكان

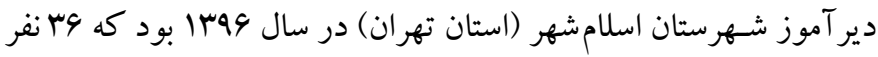
از آنها با روش نمونه گيرى در دسترس با جايدهى تصادفى در گروههاى هاى

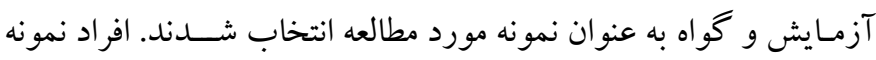

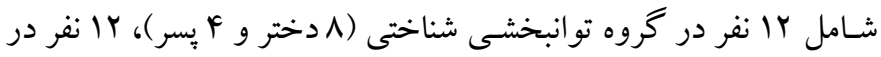

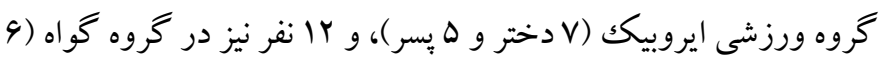

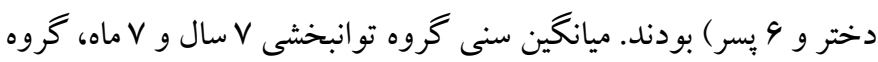

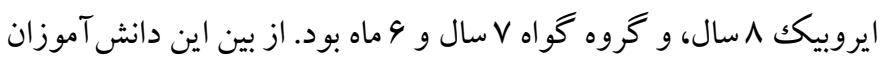

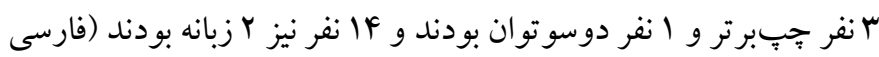

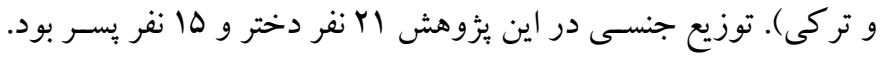
معيارهاى ورود دانش آموزان در اين يزووهش بدين شـرح بود: هيج كدام

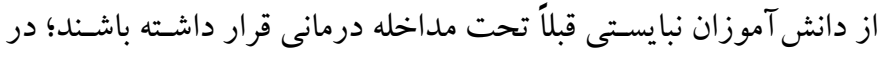

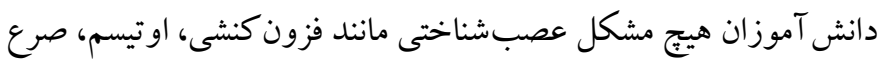

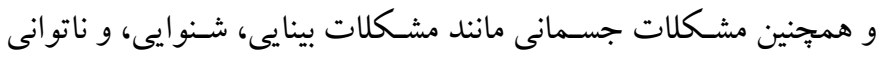

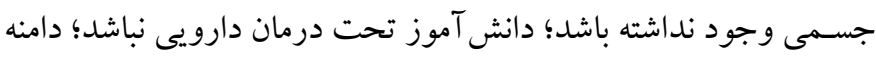

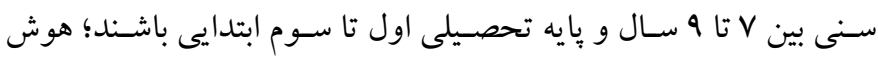

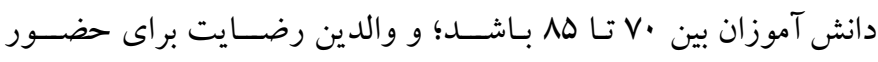

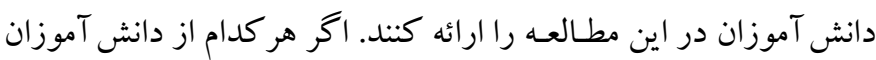

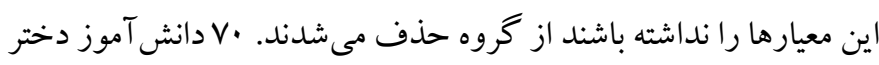

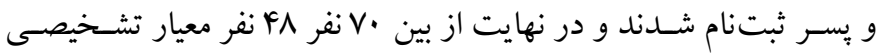

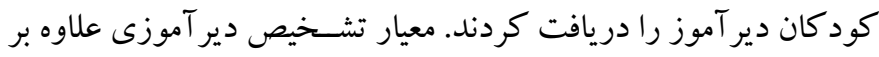

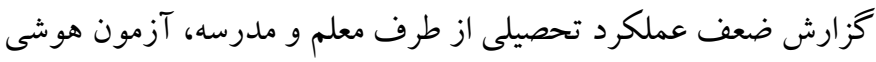

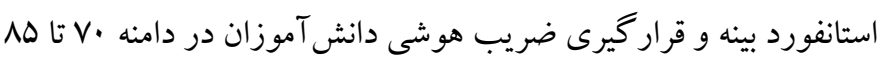

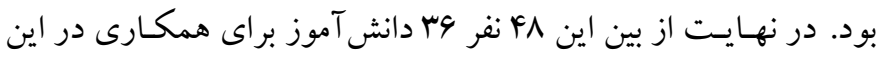
مطالعه بثزوهشى و حضور در اين بثوهش به مدت r ماه رضايت داشتند.

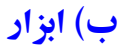
ا . يرسشنامه جمعيت شناختى 'محقق ساخته: بر /ساس / ين يرسشنامه، سن،

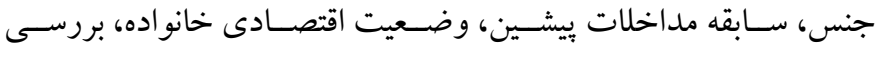

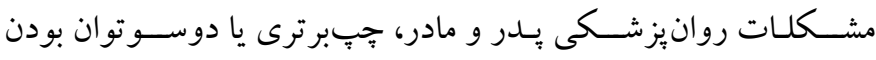
كودك، دارا بودن مشكل تحولى و خواب در كودكى، بررسى شدئ 
شـدند و هر ب نفر تحت آموزش يكك مربى قرار گرفتند. يكك مربى نيز به كرفته و روايى آن تأييد شـد. بعد از طراحى تمرينات تو انبخشى شناختى

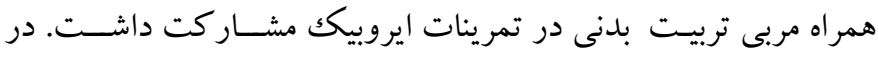

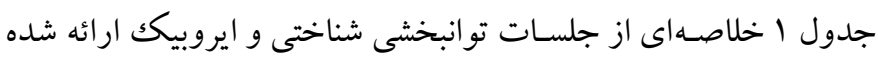

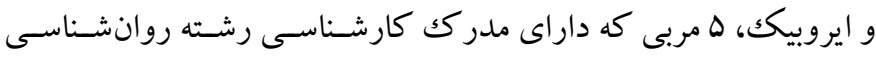

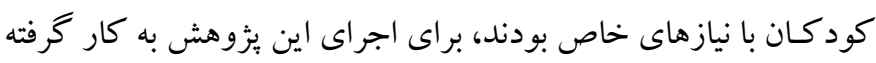
است.

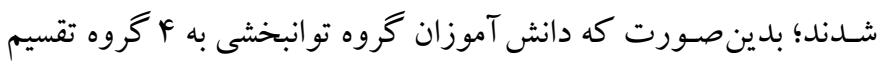

جدول ا: محتواى جلسات درمانى توانبخشى

تمرينات توانبخشى

روزهاى هفته

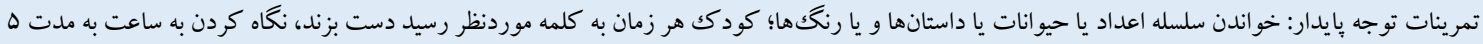

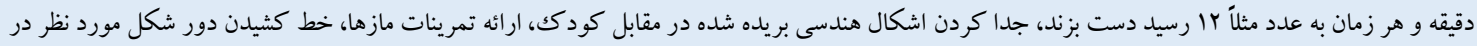

هفته نخست

$$
\text { تصوير }
$$

تمرينات توجه بايدار و انتخابى، حافظه شنيدارى و ديدارى: يكك جمله و يكك حركت به كودك ارائه مى شود و از او خواسته مىشود كه به آنجه كفته مى شود توجه

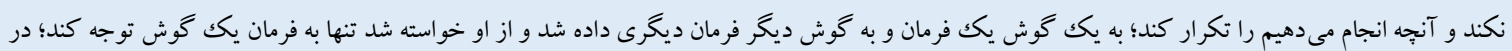

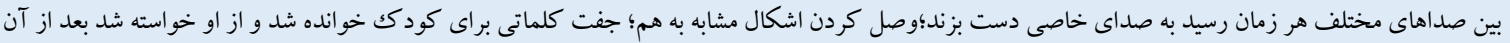

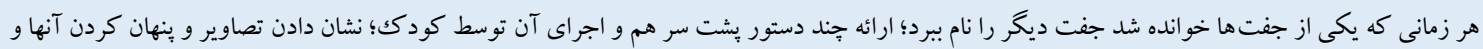

\section{هغته دوم}

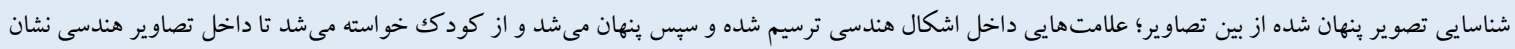
داده شده، آن علائم را ترسيم كند.

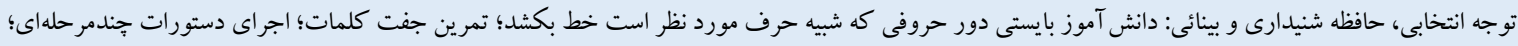

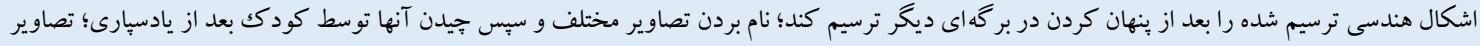

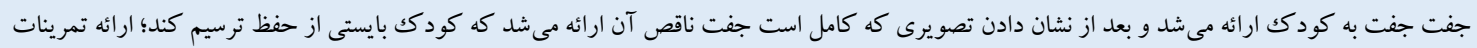

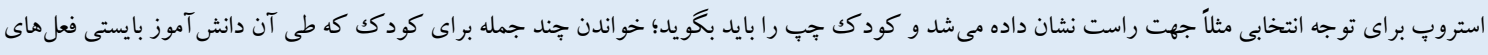
هفته سوم

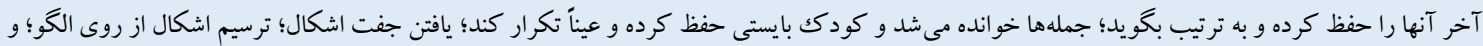

$$
\text { درست كردن اشكال از روى الكو. }
$$

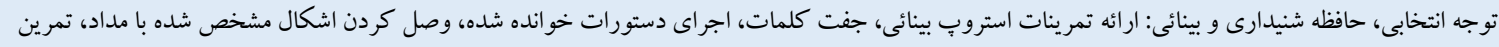

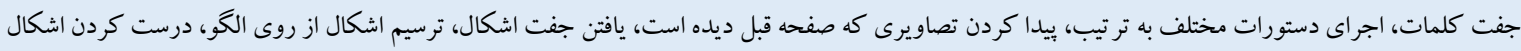

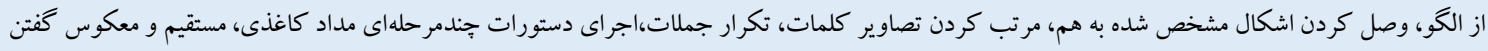

هنته جهارم

$$
\text { تصاوير و تكرار برخى تمرينات هفته سوم. }
$$

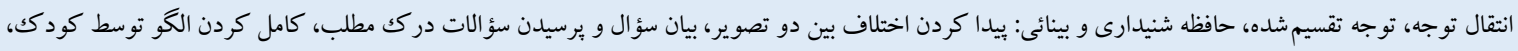

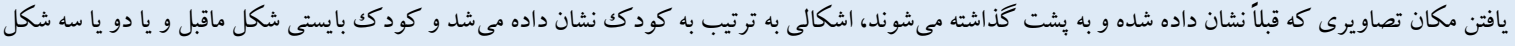

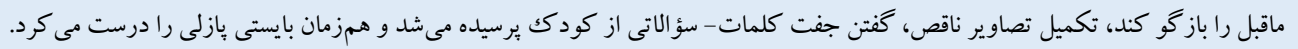

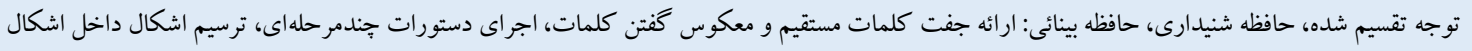

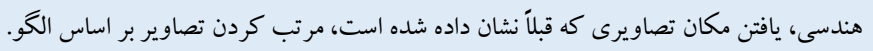

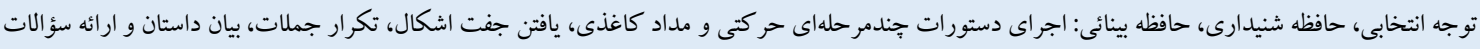

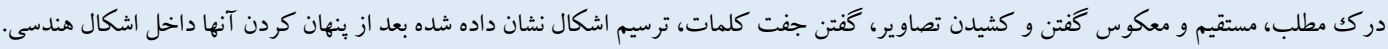

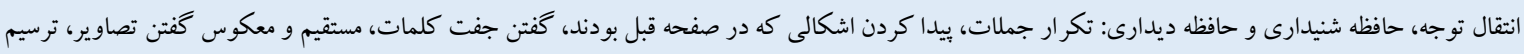

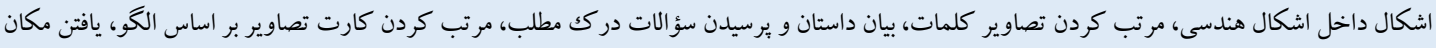

تصاويرى كه قبلاً نشان داده شده بود.

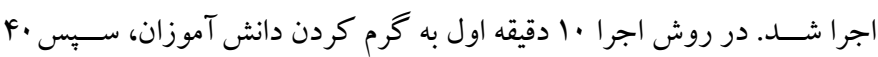

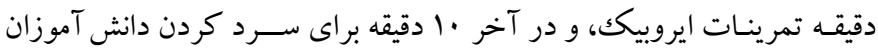

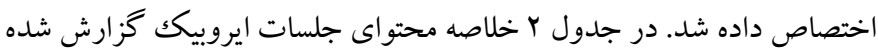

جلسات تمرينى ايروبيك

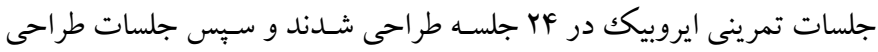

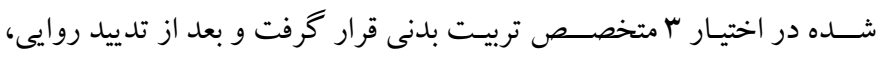

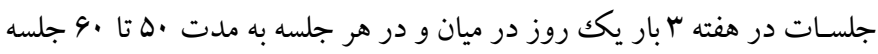




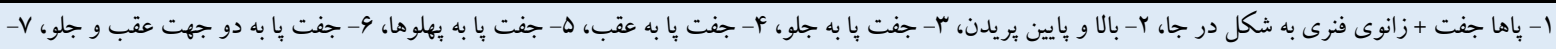

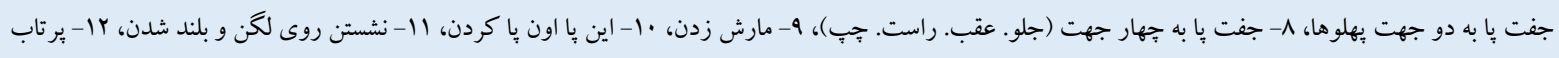

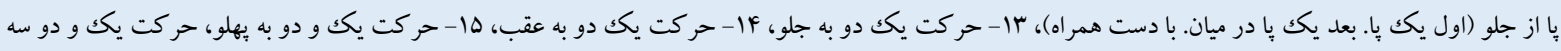

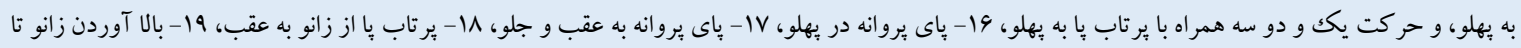

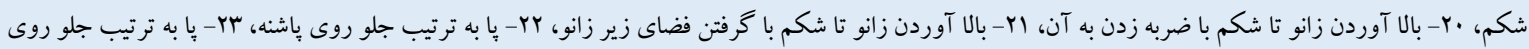

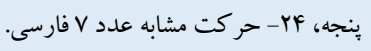

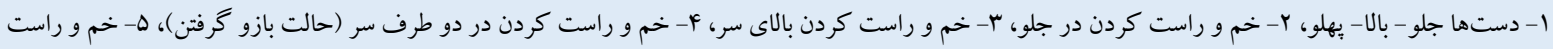

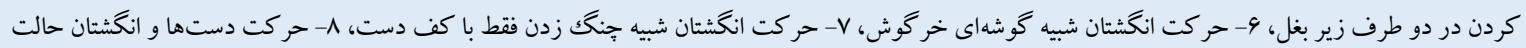

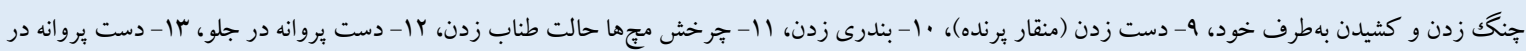

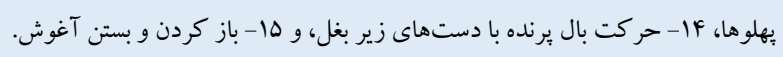

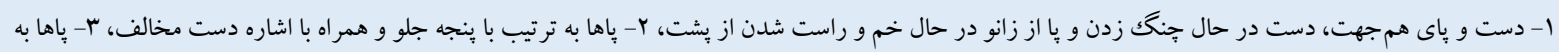

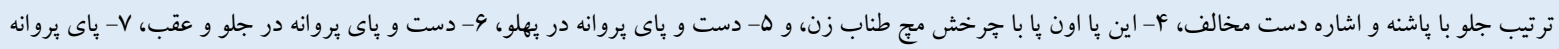

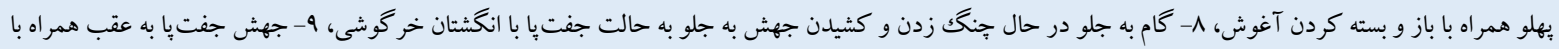

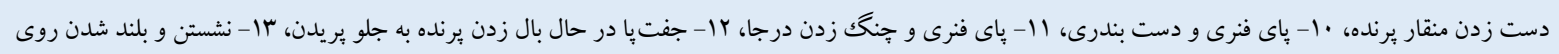

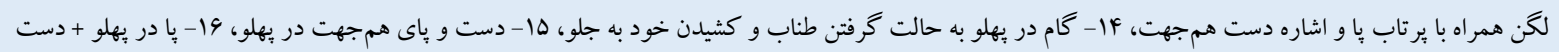

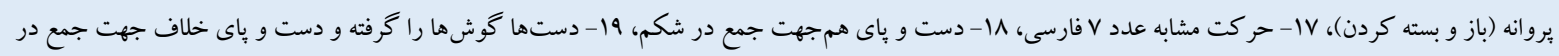

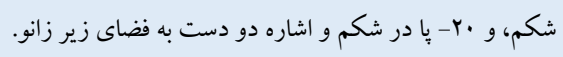

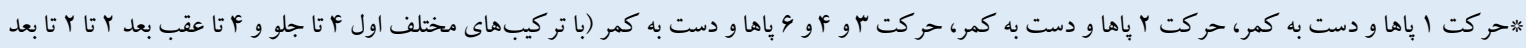

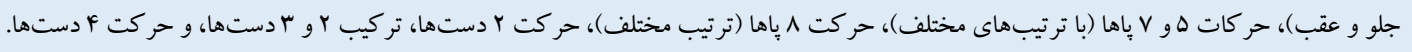

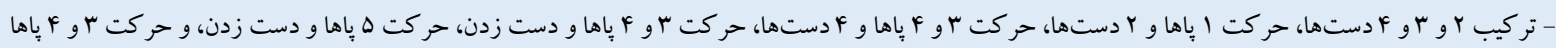

$$
\text { + }
$$

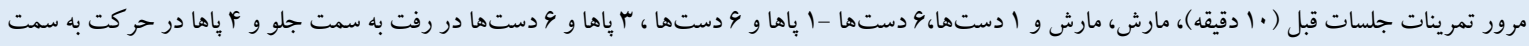

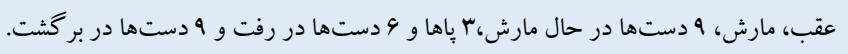

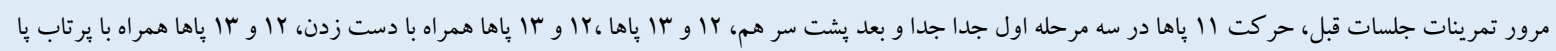

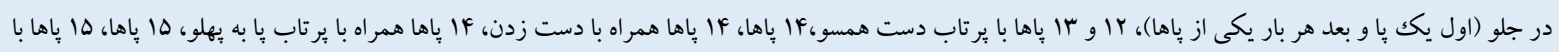

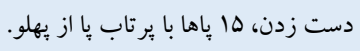

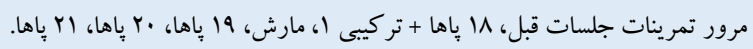

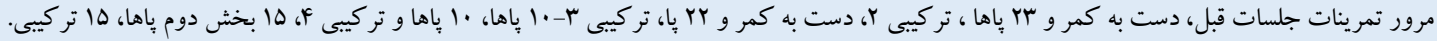

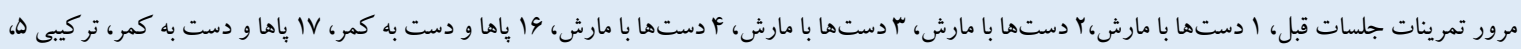

$$
\text { تر كيبى 4-، وتر كيبى vi }
$$

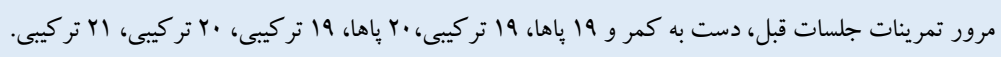

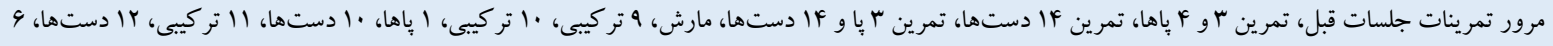

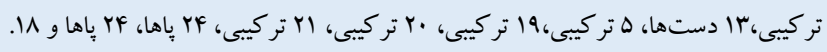
حركات تركيبى

هفته اول (جلسات 1، r)

(r

هفته دوم (جلسات f)، ه،

حركت ياها حر كات دست

هفته سوم (جلسات V،

$(9 \sqrt{ }$

هنته جهارم (جلسات

(IT ، I) ،

هفته ينجم (جلسات با،

(1061)

هفته ششم (جلسات 19،

(IA ، IV

هفته هفتم (جلسات 19،

(Y) , r.

هفته هشتم (جلسات YY،

(YF , T
دختر انسه و يُســرانسه مبنى بر معرفى و ثبـت نام دانش آموزانى كه در همه دروسـشان ضعيف هستند، انجام شد. در مرحله نهايى نمونه گيرى وس نفر
د) روش اجرا: در ابتدا با كسـب مجوز از آموزشويرورش اسـلامشهر و سـازمان دانش آموزان استثنايى استان تهر ان، اطلاعيه اى در تمامى مدارس 
به بنظور بررسى اثربخشى مداخلات انجام شد. به گروه گواه توضيح داده

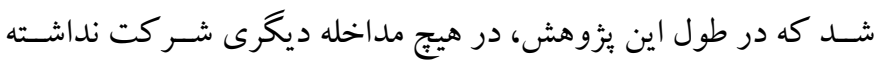

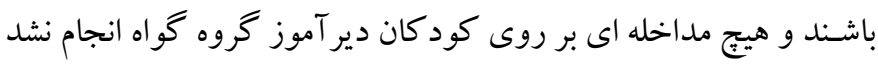

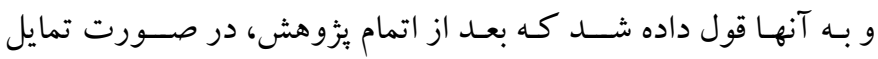
بهــورت رايكان تحت مداخله توانبخشسى شـناختى و يا ايروبيكك قرار خو اهند كرفت.

\section{يافتهها}

براى بررسى اين فرضيه كه بين ب گروه توانبخشى شناختى، ايروبيك و كروه گواه بعد از ارائه مداخله تفاوت معنى دارى وجود دود دارد، ابتدا نتايج توصسيفى در جـدول الارائه شــده اســت. همجنين نتايج جدول نتايج كـالمو گروف -اســميرنف براى بررسـى نرمـال بودن توزيع متغيرهـا در

$$
\text { كروهها گز ارش شده است. }
$$

انتخاب شـده و به ץ گروه تقسيم شدند. در مرحله بعدى، س گروه (كروه مـداخله ايروبيكك و مداخله شـناختى و گواه) از نظر هوش و مؤلفه هاى

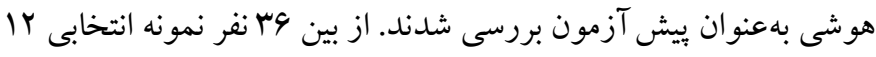

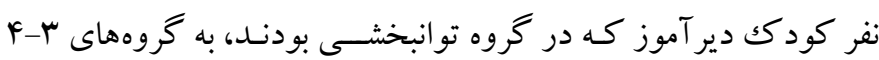

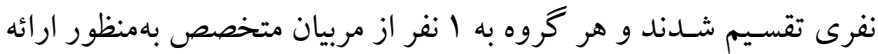
آموزش سـيرده شد. بهمنظور هماهنكى براى ارائه مداخله بين اين مربيان،

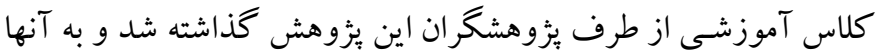

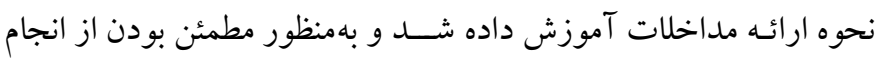

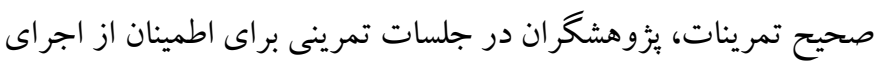

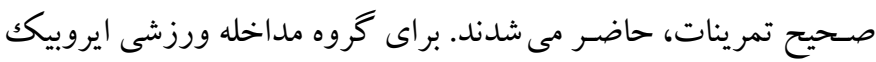

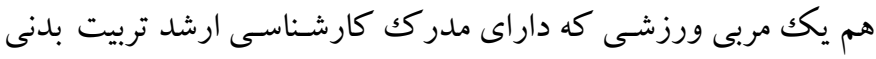
بود انتخاب شــد و جلسـات ورزش ايروبيكك براى ارائه مداخله به ايشـان

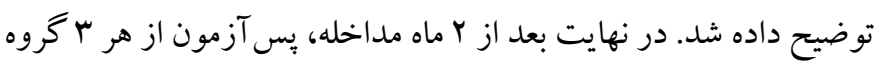

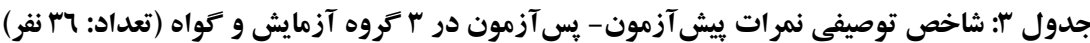

\begin{tabular}{|c|c|c|c|c|c|c|}
\hline $\mathbf{P}$ & K-SZ & انحر اف استاندارد & ميانكين & كروه & وضعيت & متغيرها \\
\hline$\cdot / T Y$ & $\cdot / M V Y$ & $r / 19$ & $V / F$ & توانبخشى شناختى & & \multirow{6}{*}{ حافظه فعال بينائى } \\
\hline$\cdot / r$ & ./NFY & $r / \Lambda$ & $9 / N \Delta V$ & ايروبيك & يش آزمون & \\
\hline$\cdot / r$ & $\cdot / T F \mid$ & $1 / 0 F 9$ & v & كواه & & \\
\hline$\cdot / 1$ & $\cdot / \mathrm{Frr}$ & $1 / \pi+1$ & $11 / 9$ & توانبخشى شناختى & & \\
\hline$\cdot / r$ & $\cdot / r r q$ & r/aFG & Q/YAS & ايروبيك & يس آزمون & \\
\hline$\cdot / r$ &.$/ 210$ & l/ArF & $V / 199$ & كواه & & \\
\hline$\cdot / r$ & . $/$ rrf & $r / 91 \Delta$ & 9 & توانبخشى شناختى & & \multirow{18}{*}{ يردازش غير كلامى ديدارى فضايى كافى } \\
\hline.$/ 1 \mathrm{~V}$ & $\cdot / \mathrm{TV} \Delta$ & r/ars & $\mathrm{r} / \mathrm{\Delta VI}$ & ايروبيك & ي يش آزمون & \\
\hline$\cdot / r$ & $\cdot / \pi r$. & $f / .19$ & $9 / 0$ & كواه & & \\
\hline$\cdot / r \Lambda$ & .498 & $r / A \wedge A$ & $V / r$ & توانبخشى شناختى & & \\
\hline$\cdot / r$ & /rif & $r / N F 1$ & 4 & ايروبيك & يس آزمون & \\
\hline$\cdot / r$ &.$/ 109$ & $r / T / Q$ & $9 / 199$ & كواه & & \\
\hline$\cdot / r$ & $\cdot / r \cdot 1$ & 1/9vr & $r / 4$ & توانبخشى شناختى & & \\
\hline$\cdot / r$ &.$/ 194$ & INTY & $r$ & ايروبيك & بيش آزمون & \\
\hline$\cdot / r$ & .rir & YNIF & F/NTr & كواه & & \\
\hline.$/ .81$ & $\cdot / 419$ & $r /$ ral & r & توانبخشى شناختى & & \\
\hline .1 .91 & $\cdot / 791$ & r/IrA & T/YAS & ايروبيك & يس"آزمون & \\
\hline$\cdot / r$ & . & $r / M$ & $\Delta / \Delta$ & كواه & & \\
\hline$\cdot / r$ &.$/ r 11$ & r/ors & 4 & توانبخشى شناختى & & \\
\hline$\cdot / r$ & /rif & 1/9Tr & $\Delta$ & ايروبيك & ي يـش آزمون & \\
\hline$\cdot / r$ & ./rrی & I/ArF & V/Arr & 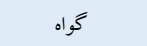 & & \\
\hline$\cdot / r$ &.$/ 198$ & $r / r \cdot r$ & N/9 & توانبخشى شناختى & \multirow{3}{*}{ بِس آزمون } & \\
\hline . /IFF &.$/ r 99$ & $r / \Delta \Lambda$ & VNIF & ايروبيك & & \\
\hline$\cdot / r$ & ./Trs & r/A9A & $v$ & كواه & & \\
\hline
\end{tabular}

تحليل آمار استنباطى گزارش شده است. در برخى متغيرها با توجه به اين

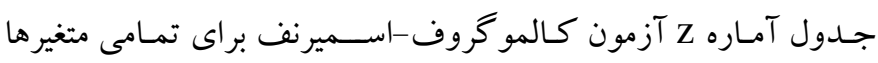

نتـايج آمـار توصـيفى در جـدول س، بـالـاتر بودن ميانگين در برخى

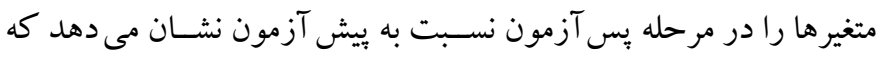

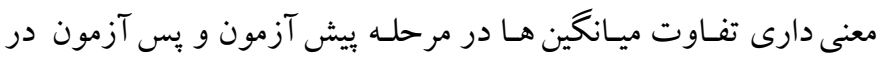


در گروهها برابر اسـت. نتايج آزمون باكس براى بررسى برابرى ماتريس

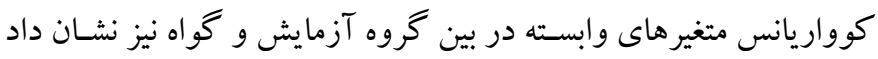

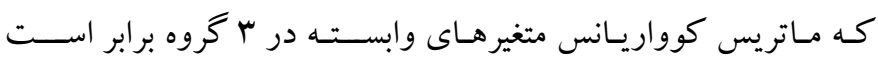
(Box M =V9/F94، F=r/YAV،P=•//V) براى بررسى معنى دارى رابطه مؤلفه هاى شـناختى نشـان داد كه بين اين

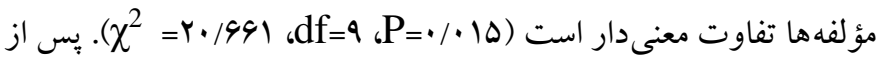
بررسى بيشفرض هاى تحليل كوواريانس تندمتغيرى، نتايج آزمون نشان

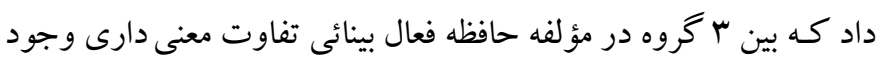

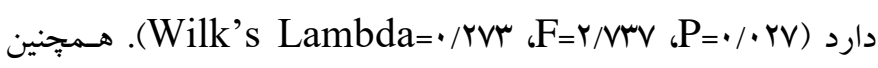

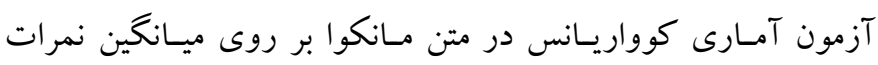

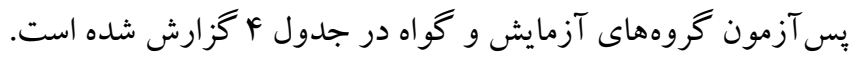

معنىدار نيست؛ بنابر اين مىتوان نتيجه گرفت كه توزيع اين متغيرها نرمال است. براى بررسى تأثير مداخلات توانبخشى و ايروبيك در دانش آموزان

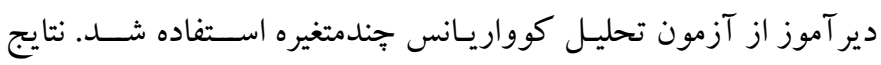

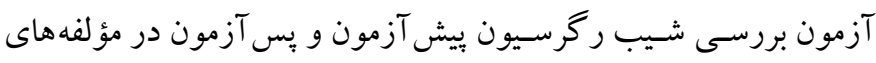

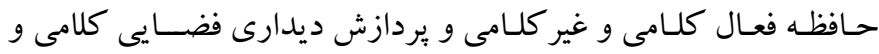

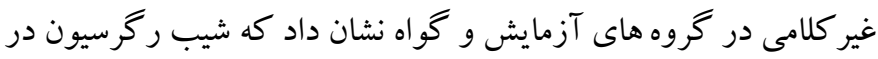

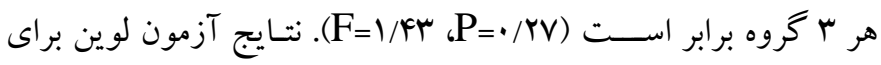

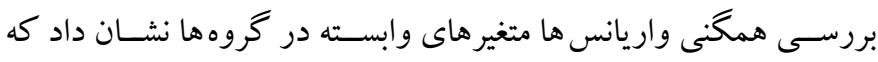

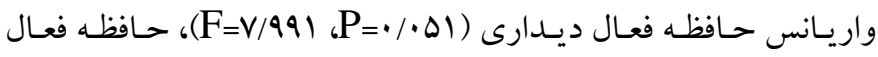
كـلـامى (F=•/rVD

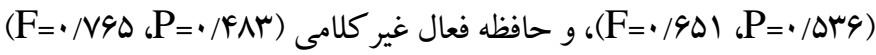

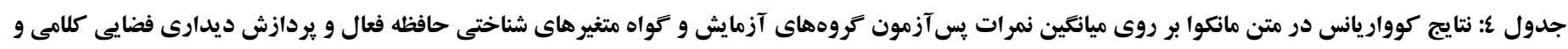
غير كلامى

\begin{tabular}{|c|c|c|c|c|}
\hline توان آزمون & اندازه اثر & $\mathbf{P}$ & $\mathbf{F}$ & متغير ها \\
\hline$\cdot / \wedge$. & $\cdot / \Delta F$ & $* . / .14$ & $9 / 494$ & حافظه فعال بينائى \\
\hline$\cdot / r$ & $\cdot / \mathrm{IV}$ & $\cdot / M+1$ & $1 / M M$ & يردازش غير كلامى ديدارى فضايى \\
\hline$\cdot / \cdot v_{1}$ & $\cdot / \cdot r t$ & •/Аケ^ & $\cdot / \Lambda$ & حافظه فعال كلامى \\
\hline 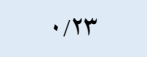 & $\cdot / r$ & - rar & $1 / \pi / 1$ & يردازش كلامى ديدارى فضايى \\
\hline
\end{tabular}

نهايت بهمنظور تعيين اينكه از بين سه گروه كدام يك تفاوت معنى دارى در حافظه فعال بينائى دارند، از آزمون تعقيبى توكى استفاده شد كه نتايج آن در جدول ها آورده شده است.

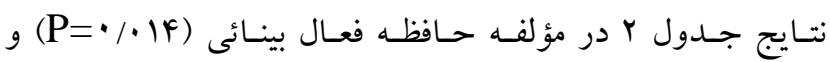
(F=9/Far)

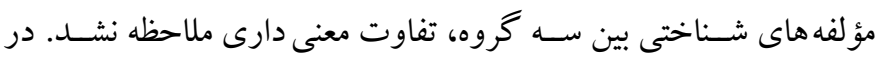

جدول ه. آزمون تعقيبى توكى براى شناسايى تفاوت جفت ميانكينها

\begin{tabular}{|c|c|c|c|c|c|}
\hline sig & انحر اف استاذدارد & تفاوت ميانكينها & & كروهها & متغير \\
\hline$\cdot / r^{4}$ & $1 / 941$ & r/TIF & ايروبيك & توانبخشى & \\
\hline.$/ .4$ & $1 / 941$ & $* 4 / \& \pi$ & گروه گواه & توانبخشى & حافظه فعال بينائى \\
\hline . & $1 / \Delta \Delta 4$ & $r / 119$ & كروه گَواه & ايروبيك & \\
\hline
\end{tabular}

شـد. نتايج اين ئزوهش نشـان داد كه بين دو گروه توانبخشى و ايروبيكك

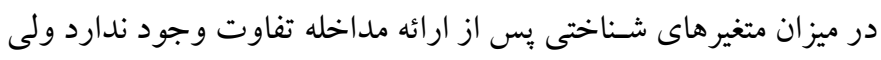

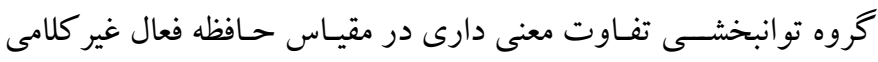

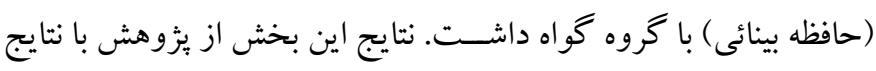

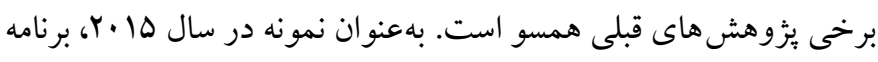

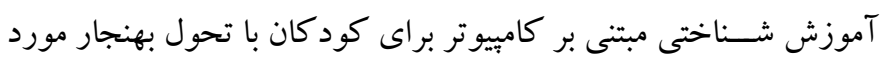

با توجه به نتايج جدول ب درباره آزمون توكى، بين گروه توانبخشى

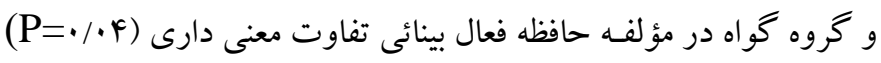

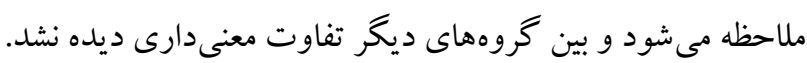
بحث و نتيجه كيرى

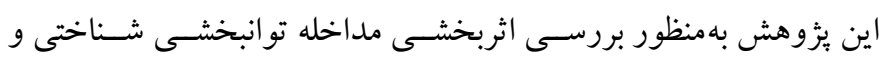

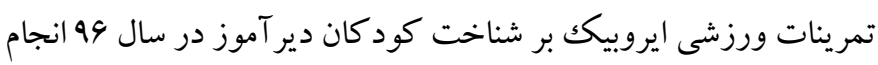


ريتميكك بر افز ايش هوش و حافظه هستند. بهعنوان مثال در مطالعه مرورى

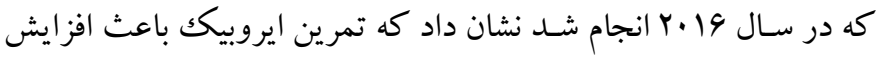

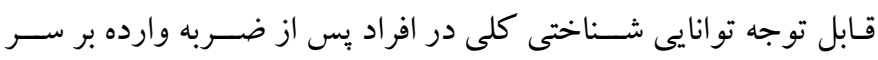

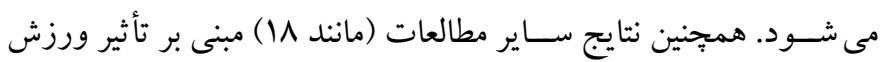

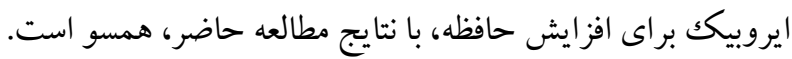

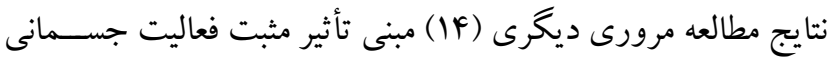

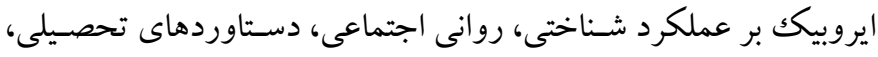

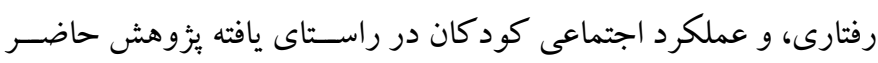

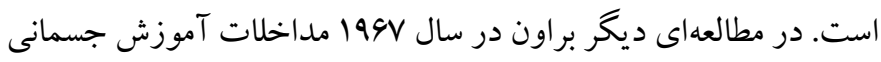
را روى ·F كودكك انجام داد و از ابزارهاى هوش استانفورد بينه و واينلند براى ســنجش متغيرها اسـتفاده كرد. نتايج نشــان داد كود كانى كه در ورزش شـركت داشـتند نسبت به گروه گو اه، در هر دو آزمون هوشى و تحول اجتماعى روند افزايشى داشتند. همجنين نتايج مطالعات كود (IV)

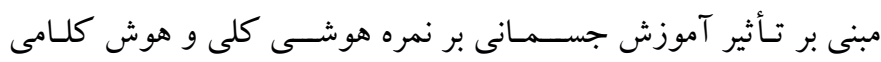
دانش آموزان كم توان ذهنى خفيف، با يافته مطالعه حاضـر، همسيو است. نتايج به دسـت آمده در اين مطالعه و ساير مطالعات مشابه را مى توان اين

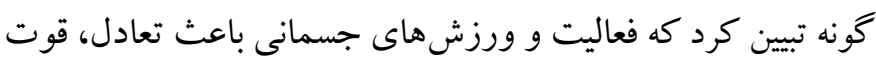
عضلانى، و كيفيت زندكى در افراد با مشكلات ذهنى مى شود ( •(1)، زيرا ورزش نيازمند اسـتفاده از توجه، حافظه، بردازش منطقى، و تحر كى

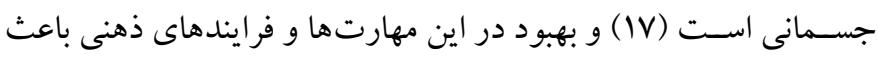

$$
\text { بهبود وضعيت شناختى در افر اد دير آموز مى شود. }
$$

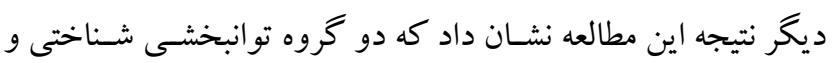
ايروبيكك بـا گروه گواه تفـاوت معنى دارى در مقيـاس هايى مانند حافظه فعـال كلامى و اسـتـدلال ديدارى فضـايى كلامى و بينايى بعد از مداخله

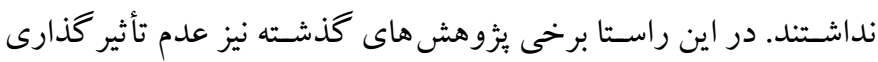

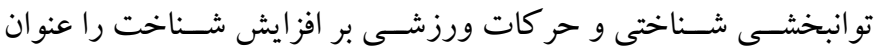

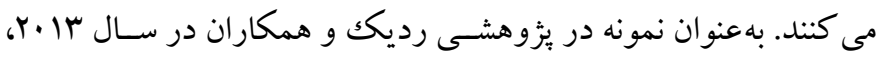
طى يزٔوهش فر اتحليل عنو ان كردند كه برنامه هاى توانبخشى حافظه فعال

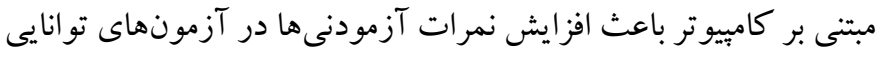

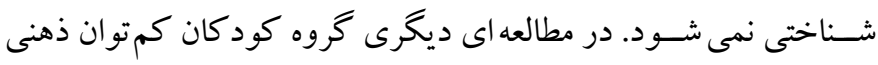

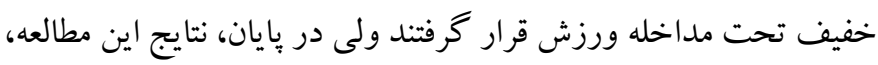
اثربخشى اين مداخله را بر ضـريب هوشى اين كود كان نشان نداد (Fr).
اسـتفاده قرار گرفت كه نتايج آن نشـان داد برنامه آموزش شـناختى براى افزايش هوش تأثير مثبتى بر تحول شـناختى كود كان دارد ( •(F). همجنين

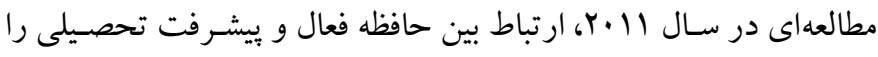

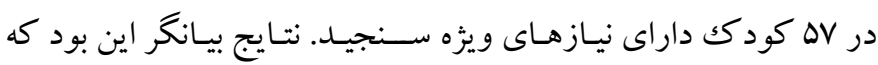
مداخلات شناختى باعث افزايش حافظه فعال كود كان و در نتيجه يِيشرفت در خواندن مىشود؛ بنابر اين آموزش حافظه فعال عامل مهمى در بيشرفت

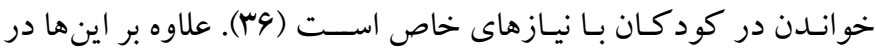

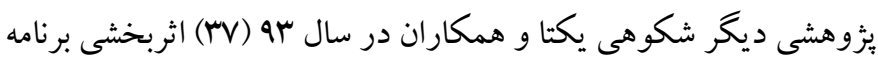

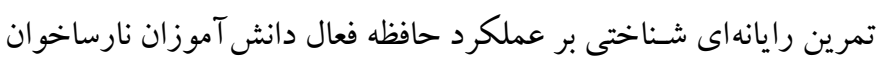
را سـنجيدند كه نتايج آن بيانكر تأثير معنى دار اين برنامه بر حافظه فعال

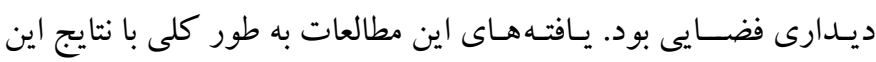
ئزوهش همسو است. در تبيين يافته به دست آمده در اين مطالعه مى توان به نتايج مطالعات

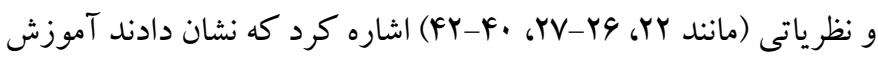

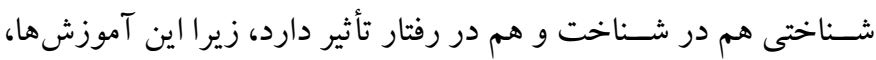

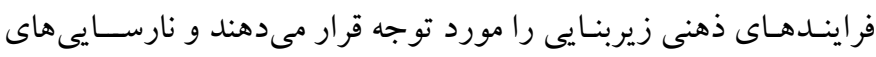

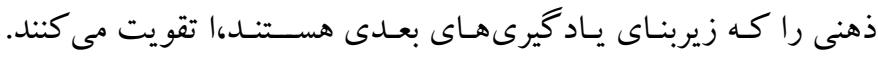

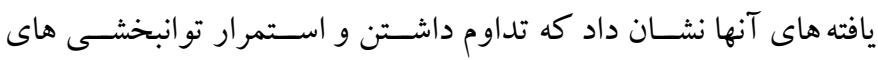
شـناختى باعث بهبود تو انمندى هاى ذهنى افراد با تاخيرات ذهنى مى شود

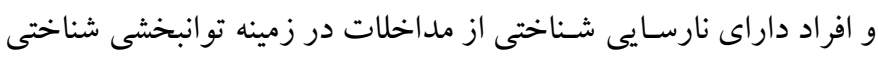

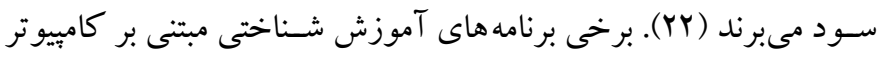

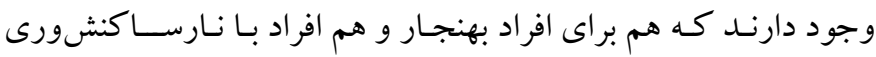

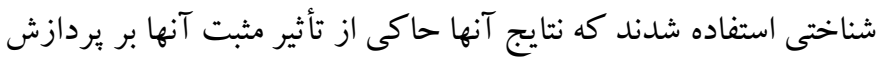

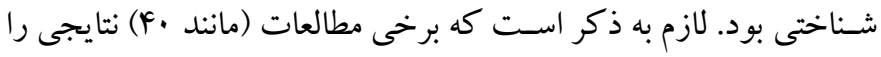

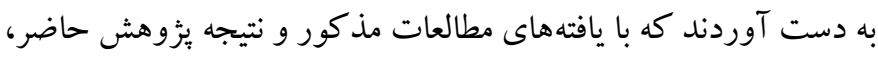

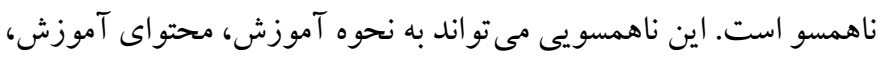
راهبردهاى مورد استفاده، و تعداد جلسات مربوط باشد. لـون.

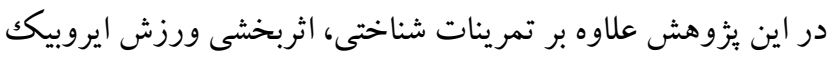

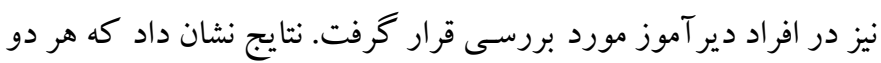

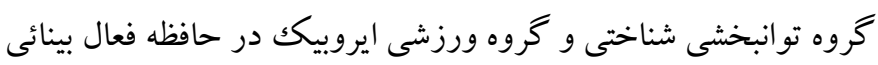

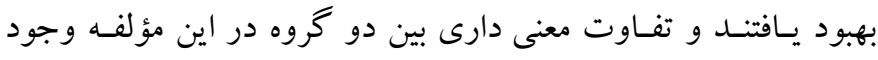

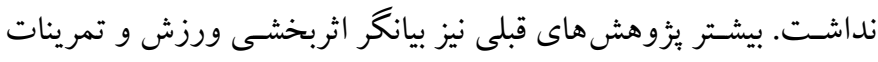


اين بثزوهش بـا محـدوديـت هـايى مواجه بوده اســت كه در دقت و تعميمدهى نتايج بايد به آنها توجه داشــت. از جمله محدوديت هاى اين

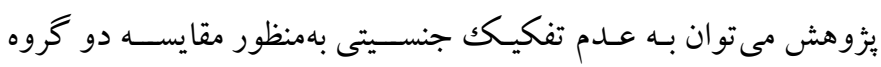

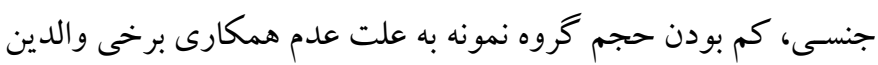

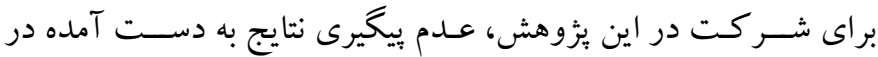

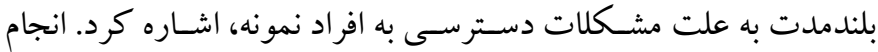

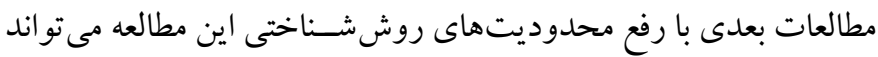

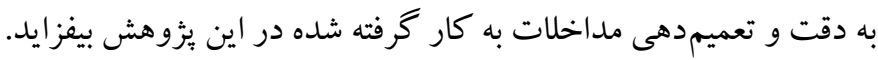

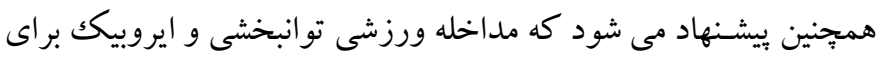

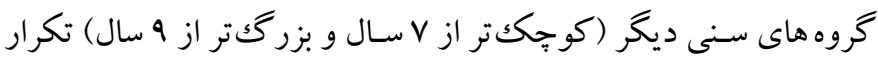
شــود، زيرا اين دو نوع مــداخلـه در ســنين مختلف ممكن اسـتـت نتايج

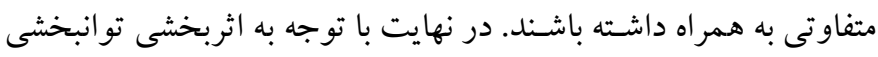

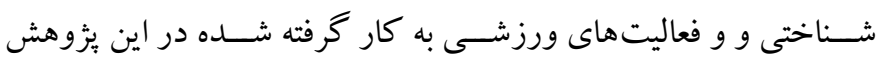

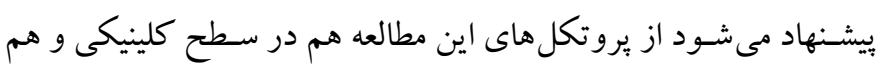

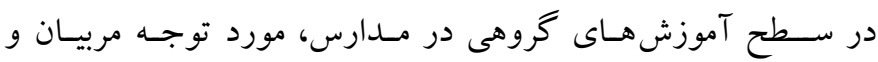
متخصصان قرار گيرد.

تشكر و قدردانى: اين مطالعه بهصورت مستقل اجرا شده است و مجوز آن از

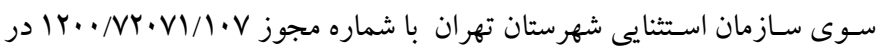

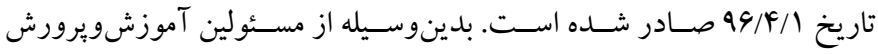
اسـلام شهر و اداره استثنائى شهرستان هاى تهران و همجِنين سر كار خانم رمضانى

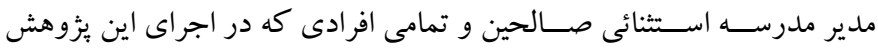
مشار كت داشتند تشكر و قدردانى مىشود.

تضــاد منافع: اين يزوهش براى نويسـند كان هيج گونه تضــاد منافع به دنبال

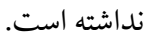

نتـايج يزوهش ديخرى بيـانكر اين بود كـه تـأثير آموزش شــــاختى و توانبخشى شناختى بر حافظه فعال، بستخى به جنسيت، اختلالات همر اه، و و

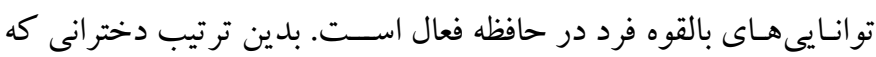

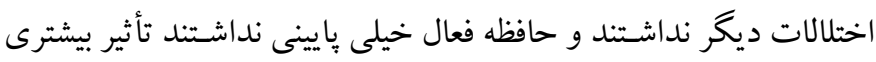
از مداخله دريافت مى كنند؛ بنابراين ظرفيت اوليه حافظه فعال در اثربخشى

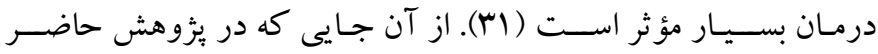

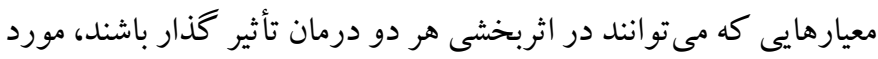

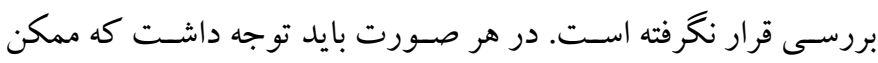

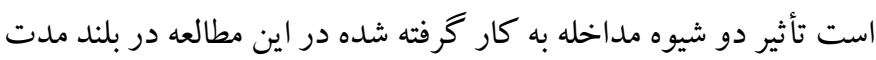
متفاوت باشد و تفاوت معنادارى بين آنها مشاهده شود. بهور كلى در تبيين نتايج به دسـت آمده مبنى بر اثربخشى تمرينات

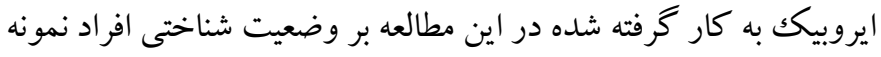

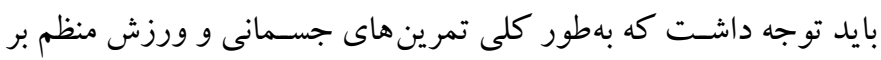

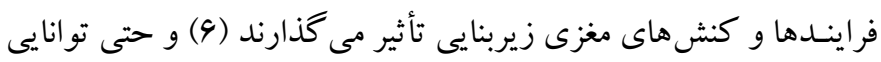

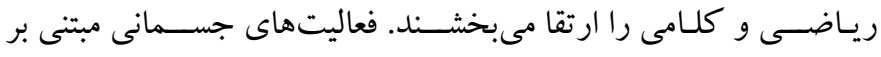
ايروبيك نيز تغييرات سـاختارى و كنشى در مغز ايجاد مى كند (19) كه در نتيجه باعث بهبود كار كردها و عملكرد شناختى دانش آموزان مى شوند

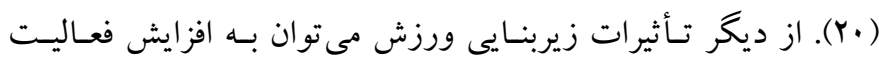

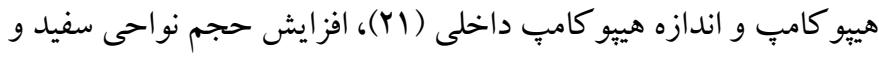

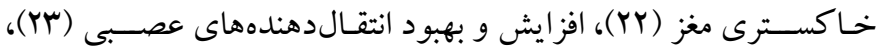
افزايش جريان خون (YD)، و افزايش انعطاف بذيرى سينايسى (Y) اشاره

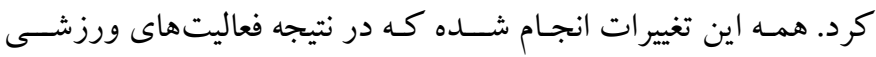

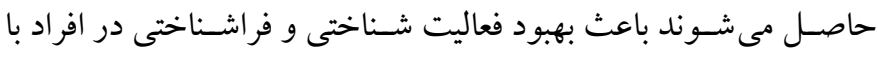
تاخيرات ذهنى و شـناختى مى شوند كه در مطالعه حاضر نيز همين يافتها تأيد شد. 


\section{References}

1. Afrooz GA. Psychology \& rehabilitation of Down syndrome children. 5th Edition. Tehran: University of Tehran press; 2010, p: 26. [Persian]

2. Szumski G, Firkowska-Mankiewicz A, Lebuda I, Karwowski M. Predictors of success and quality of life in people with borderline intelligence: The special school label, personal and social resources. J Appl Res Intellect Disabil. 2018; 31(6): 1021-1031. [Link]

3. Khoshou'ei M-S, Mirlohi F-S. Slow-learner student, verbal and nonverbal intelligence, Wechsler, Leiter, Goodenough. Archives of Rehabilitation. 2014; 15(1): 37-44. [Persian]. [Link]

4. Di Blasi FD, Buono S, Cantagallo C, Di Filippo G, Zoccolotti P. Reading skills in children with mild to borderline intellectual disability: a cross-sectional study on second to eighth graders. J Intellect Disabil Res. 2019; 63(8): 1023-1040. [Link]

5. Stefanelli S, Alloway TP. Mathematical skills and working memory profile of children with borderline intellectual functioning. J Intellect Disabil. 2018; 1744629518821251. [Link]

6. Hillman $\mathrm{CH}$, Erickson KI, Kramer AF. Be smart, exercise your heart: exercise effects on brain and cognition. Nat Rev Neurosci. 2008; 9(1): 58-65. [Link]

7. Sibley BA, Etnier JL. The relationship between physical activity and cognition in children: a metaanalysis. Pediatr Exerc Sci. 2003; 15(3): 243-256. [Link]

8. Taras H. Physical activity and student performance at school. J Sch Health. 2005; 75(6): 214-218. [Link]

9. Smith PJ, Blumenthal JA, Hoffman BM, Cooper H, Strauman TA, Welsh-Bohmer K, et al. Aerobic exercise and neurocognitive performance: a metaanalytic review of randomized controlled trials. Psychosom Med. 2010; 72(3): 239-252. [Link]

10. Bartlo P, Klein PJ. Physical activity benefits and needs in adults with intellectual disabilities: systematic review of the literature. Am J Intellect Dev Disabil. 2011; 116(3): 220-232. [Link]

11. Davis CL, Tomporowski PD, Boyle CA, Waller JL, Miller PH, Naglieri JA, et al. Effects of aerobic exercise on overweight children's cognitive functioning: a randomized controlled trial. Res Q Exerc Sport. 2007; 78(5): 510-519. [Link]

12. Lezak MD, Howieson DB, Loring DW, Hannay HJ, Fischer JS. Neuropsychological assessment, 4th ed. New York, NY, US: Oxford University Press; 2004. [Link]
13. Tandon PS, Tovar A, Jayasuriya AT, Welker E, Schober DJ, Copeland K, et al. The relationship between physical activity and diet and young children's cognitive development: A systematic review. Prev Med Rep. 2016; 3: 379-390. [Link]

14. Lees C, Hopkins J. Effect of aerobic exercise on cognition, academic achievement, and psychosocial function in children: a systematic review of randomized control trials. Prev Chronic Dis. 2013; 10: E174. [Link]

15. Welk GJ, Jackson AW, Morrow JR, Haskell WH, Meredith MD, Cooper KH. The association of healthrelated fitness with indicators of academic performance in Texas schools. Res Q Exerc Sport. 2010; 81(3 Suppl): S16-23. [Link]

16. Fedewa AL, Ahn S. The effects of physical activity and physical fitness on children's achievement and cognitive outcomes: a meta-analysis. Res Q Exerc Sport. 2011; 82(3): 521-535. [Link]

17. Tomporowski PD, Davis CL, Miller PH, Naglieri JA. Exercise and children's intelligence, cognition, and academic achievement. Educ Psychol Rev. 2008; 20(2): 111-131. [Link]

18. Zheng G, Zhou W, Xia R, Tao J, Chen L. Aerobic exercises for cognition rehabilitation following stroke: a systematic review. J Stroke Cerebrovasc Dis. 2016; 25(11): 2780-2789. [Link]

19. Singh A, Uijtdewilligen L, Twisk JWR, van Mechelen W, Chinapaw MJM. Physical activity and performance at school: a systematic review of the literature including a methodological quality assessment. Arch Pediatr Adolesc Med. 2012; 166(1): 49-55. [Link]

20. Kourakli M, Altanis I, Retalis S, Boloudakis M, Zbainos D, Antonopoulou K. Towards the improvement of the cognitive, motoric and academic skills of students with special educational needs using Kinect learning games. Int $\mathbf{J}$ Child Comput Interact. 2017; 11: 28-39. [Link]

21. Burdette JH, Laurienti PJ, Espeland MA, Morgan A, Telesford Q, Vechlekar CD, et al. Using network science to evaluate exercise-associated brain changes in older adults. Front Aging Neurosci. 2010; 2: 23. [Link]

22. Cornish K, Cole V, Longhi E, Karmiloff-Smith A, Scerif G. Mapping developmental trajectories of attention and working memory in fragile $\mathrm{X}$ syndrome: developmental freeze or developmental change? Dev Psychopathol. 2013; 25(2): 365-376. [Link]

23. Chaddock-Heyman L, Erickson KI, Holtrop JL, Voss MW, Pontifex MB, Raine LB, et al. Aerobic fitness is 
associated with greater white matter integrity in children. Front Hum Neurosci. 2014; 8: 584. [Link]

24. Eriksson J, Kalpouzos G, Nyberg L. Rewiring the brain with repeated retrieval: a parametric fMRI study of the testing effect. Neurosci Lett. 2011; 505(1): 3640. [Link]

25. Hartman E, Smith J, Houwen S, Visscher C. Skillrelated physical fitness versus aerobic fitness as a predictor of executive functioning in children with intellectual disabilities or borderline intellectual functioning. Res Dev Disabil. 2017; 64: 1-11. [Link]

26. Hötting K, Röder B. Beneficial effects of physical exercise on neuroplasticity and cognition. Neurosci Biobehav Rev. 2013; 37(9 Pt B): 2243-2257. [Link]

27. Rasberry CN, Lee SM, Robin L, Laris BA, Russell LA, Coyle KK, et al. The association between schoolbased physical activity, including physical education, and academic performance: a systematic review of the literature. Prev Med. 2011; 52(Suppl 1): S10-20. [Link]

28. Tomporowski PD, McCullick B, Pendleton DM, Pesce C. Exercise and children's cognition: The role of exercise characteristics and a place for metacognition. J Sport Health Sci. 2015; 4(1): 47-55. [Link]

29. Golubović Š, Maksimović J, Golubović B, Glumbić N. Effects of exercise on physical fitness in children with intellectual disability. Res Dev Disabil. 2012; 33(2): 608-614. [Link]

30. Klingberg T. Training and plasticity of working memory. Trends Cogn Sci (Regul Ed). 2010; 14(7): 317-324. [Link]

31. Söderqvist S, Nutley SB, Ottersen J, Grill KM, Klingberg T. Computerized training of non-verbal reasoning and working memory in children with intellectual disability. Front Hum Neurosci. 2012; 6: 271. [Link]

32. Van der Molen MJ, Van Luit JEH, Jongmans MJ, Van der Molen MW. Memory profiles in children with mild intellectual disabilities: strengths and weaknesses. Res Dev Disabil. 2009; 30(6): 12371247. [Link]

33. Alloway TP, Alloway RG. Investigating the predictive roles of working memory and IQ in academic attainment. J Exp Child Psychol. 2010; 106(1): 20-29. [Link]

34. Bull R, Scerif G. Executive functioning as a predictor of children's mathematics ability: inhibition, switching, and working memory. Dev Neuropsychol. 2001; 19(3): 273-393. [Link]
35. Maehler C, Schuchardt K. The importance of working memory for school achievement in primary school children with intellectual or learning disabilities. Res Dev Disabil. 2016; 58: 1-8. [Link]

36. Dahlin KIE. Effects of working memory training on reading in children with special needs. Read Writ. 2011; 24(4): 479-491. [Link]

37. Shokoohi-Yekta M, Lotfi S, Rostami R, Arjmandnia AA, Motamed-Yeganeh N, Sharifi A. The effectiveness of computerized cognitive training on the working memory performance of children with dyslexia. Bimonthly Audiology - Tehran University of Medical Sciences. 2014; 23(3): 46-56. [Persian]. [Link]

38. Borella E, Carretti B, Riboldi F, De Beni R. Working memory training in older adults: evidence of transfer and maintenance effects. Psychol Aging. 2010; 25(4): 767-778. [Link]

39. Poloczek S, Büttner G, Hasselhorn M. Phonological short-term memory impairment and the word length effect in children with intellectual disabilities. Res Dev Disabil. 2014; 35(2): 455-462. [Link]

40. Kafadar H, Akıncı Z, Çakır B. Effects of the IQ up cognitive development method on the cognitive development of 10- to 12-year-old children. Procedia Soc Behav Sci. 2015; 174: 3243-3253. [Link]

41. Van der Molen MJ, Van Luit JEH, Van der Molen MW, Klugkist I, Jongmans MJ. Effectiveness of a computerised working memory training in adolescents with mild to borderline intellectual disabilities. J Intellect Disabil Res. 2010; 54(5): 433-447. [Link]

42. Redick TS, Shipstead Z, Harrison TL, Hicks KL, Fried DE, Hambrick DZ, et al. No evidence of intelligence improvement after working memory training: a randomized, placebo-controlled study. J Exp Psychol Gen. 2013; 142(2): 359-379. [Link]

43. Farid F, Kamkary K, Safarinia M, Afroz S. The comparison of diagnostic validity of new version of tehran- stanford binet intelligence scales (TSB-5) and wechsler intelligence scales for children- fourth edition (WISC-4) in children with learning disability. Journal of Learning Disabilities. 2015; 4(2): 70-83. [Persian]. [Link]

44. Shiri Aminloo M, Kamkary K, Shokrzadeh S. The concurrent validity of the new version of the TehranStanford-Binet intelligence scale with the Wechsler intelligence scale for children-revised. Exceptional Education Journal. 2013; 7(120): 50-61. [Persian]. [Link] 